Federal Reserve Bank of Dallas

Globalization and Monetary Policy Institute

Working Paper No. 302

https://www.dallasfed.org/ /media/documents/institute/wpapers/2017/0302.pdf

\title{
Export Tax Rebates and Resource Misallocation: Evidence from a Large Developing Country ${ }^{*}$
}

\author{
Ariel Weinberger \\ University of Oklahoma \\ Qian Xuefeng \\ Zhongnan University of Economics and Law \\ Mahmut Yasar \\ UT-Arlington and Emory University
}

January 2017

\begin{abstract}
The export tax rebate (ETR) policy is one of the most frequently used policy instruments by Chinese policy makers. This paper therefore provides a vital analysis of its allocation effects. To motivate our empirical analysis for the allocation effects of the ETR policy, we first add a tax rebate to the Melitz and Ottaviano (2008) model and examine the impact of this policy on firms' markup size and resource allocation between eligible and non-eligible firms for the rebates. We use customs transactions, tax administration, and firm-level data to measure the effect of variation in export tax rebates, taking advantage of the large policy change in 2004 . A difference-indifference approach allows us to compare the production and pricing decisions of eligible versus non-eligible firms and the distributional implications. We find that an increase in tax rebates shifts production to eligible firms and that tax rebates increase allocative efficiency.
\end{abstract}

JEL codes: F13, F14, F12, F6, O19, O24, O38

\footnotetext{
Ariel Weinberger, 308 Cate Center Drive, Room 158 CCD1, Norman, OK 73019. ariel.weinberger@ou.edu. Qian Xuefeng, Zhongnan University of Economics and Law, 182 Nanhu Avenue, East Lake High-Tech Development Zone, Wuhan 430073, P. R. China. xfqian@znufe.edu.cn. Mahmut Yahar, 701 S. West St., Campus Box 19479, Arlington, TX 76019. myasar@uta.edu. We thank participants at the International Industrial Organization Conference 2016, especially our discussant Ricardo Lopez, for insightful comments. The views in this paper are those of the authors and do not necessarily reflect the views of the Federal Reserve Bank of Dallas or the Federal Reserve System.
} 


\section{Export Tax Rebates and Resource Misallocation: Evidence from a Large Developing}

\section{Country}

\section{Introduction}

Chinese exports have grown at spectacular rates since the 1980s, prompting a line of intense research on policies that have played a role in China's transformation. This paper is a contribution to this literature. Specifically, we focus on the role of China's export tax rebates (hereinafter, ETRs), which work like a negative value-added tax (VAT). The Chinese government uses ETRs to refund part of domestic taxes to Chinese exporters while taxing imports. Our focus is on how ETRs affect Chinese firms' markup rates and distort allocation of resources between its exporting and non-exporting firms.

Despite their popularity, theoretical studies find that the use of ETRs cannot promote the country's exports or improve its competitiveness (see, e.g., Feldstein and Krugman (1990)). By contrast, empirical evidence seems to indicate that trade performance is affected by VATs and rebates for exports. This is likely due to the fact that theoretical models (such as in the aforementioned paper) rely on the assumption of complete export rebates combined with VATs; therefore, incomplete rebates act as an export tax. If complete export refunds are not a given, then raising the export rebates is akin to lowering taxes on exporters. Our paper shows that ETRs are important not only because they affect export performance, but that there are allocative efficiency issues as well. A VAT system that does not fully rebate taxes to exporters creates a wedge between total revenues and total output for those exporters, and leads to an inefficient allocation of resources.

In this paper, we link the incomplete tax rebate for exporters to an aggregate measure of misallocation. We first present a model that draws on Melitz and Ottaviano (2008) and make testable predictions on how ETRs will affect exporters and non-exporters differentially. This model features heterogeneous firms and variable markups so that adding a tax to firm revenues results in a reallocation of production that is not necessarily proportional to changes in revenue, as firms pass-through a portion of tax costs/savings to their markups. A variable tax rebate allows us to frame the research question as whether trade policy should aim for a closer to "complete" rebate of VAT taxes. ${ }^{1}$ Therefore, although the tax rebate is not fully passed on to

\footnotetext{
1 "Complete" in this case would be a rebates equivalent to the VAT on exporters, which is $17 \%$ for most industries in China.
} 
lower prices, it could also be the case that the VAT itself (sans rebate) was distortionary on exporters so that the ETR acts as a way to alleviate the distortion and allow industries to get closer to an efficient allocation. Instead of viewing the rebate as a deviation from the nondistorted case, we allow the rebate to either raise or lower allocative efficiency. We find that industries with more rebate-eligible firms become relatively less efficient after 2004, when the Chinese government lowered tax rebates across most products.

This study contributes to the literature with a rigorous empirical examination of the impact of ETRs on firms' production decisions and its implication on resource allocation between exporting and non-exporting firms. This is possible by combining not only Chinese firm-level production data with customs transactions as is the case in the virtually all of the related studies (see below), but also adding data on export tax rebate rates from the State Taxation Administration (EVATR). The EVATR data set records export tax rebates at the HS 10-digit. With information in the customs database and EVATR, we can calculate a firm's average ETR to identify export performance and VAT taxes paid/rebated.

By restricting the sample to the customs transactions of exporters, we first show that an increase in rebates leads to a higher quantity sold, and, to a lesser degree, that there is evidence that eligible firms lower their prices. These are consistent with the predictions of a model with non-homothetic preferences and heterogeneous (in productivity) firms. When we aggregate to the firm level and merge with the national census that provides revenue and input data, we can then produce firm-level productivity and markup estimates. These are computed using revenue data from domestic and export sales thus obscuring the direct effect of the tax rebate, ${ }^{2}$ but since we are interested in the distributional effects we then measure the effects of the rebate policy on the reallocation of production between eligible and non-eligible firms. A difference-in-difference specification identifies the effect on eligible firms using non-eligible firms as a control group. We find that an increase in tax rebates shifts production to eligible firms and raises their profits (consistent with markups actually increasing as expected). The objective is not to capture the competition effect on entry and exit, but to capture the efficiency of the reallocation of existent resources. In our model with variable markups there are over-producing and under-producing firms, and we test whether the rebate change alleviates or exacerbates this distortion.

\footnotetext{
${ }^{2}$ We show that competition effects come into play as these rebates shift cutoffs in the domestic as well as the export market. We try to abstract from entry and exit, but these might still play a role in the effect on firm level markups.
} 
Finally, to study allocative efficiency, we aggregate the data to the industry level to produce several misallocation measures consistent with our model. Non-homothetic linear demand preferences with heterogeneous firms imply distortions due to market power dispersion. We use our firm-level data to create a markup dispersion measure at the industry-year level, and also check the covariance of markups and changes in market share as in Arkolakis et al. (2015). Additionally, since our data concerns revenues and not quantities, we also use the misallocation measures of Hsieh and Klenow (2009) that track the dispersion of estimated revenue productivity. Relatedly, we track the covariance of changes in market share with the revenue productivity measure. Dispersions in both markups and TFPR are consistent with the highproductivity firms under-producing and, conversely, the low-productivity firms over-producing. The implication is that higher dispersions represent larger misallocations. Similarly, positive growth in the covariance measures signifies a reallocation that results in lower misallocation. We find evidence that higher rebates reduce industry misallocation as both dispersion measures decrease. The covariance measures are more ambiguous as the productivity reallocation also signifies higher allocative efficiency, though we do not find this in the markup covariance.

There are a number of recent empirical studies that support the non-neutrality of export taxes. For example, Desai and Hines (2005) analyze data for 168 countries from 1950 and 2000, and obtain results consistent with VATs reducing export performance. In their own words, "countries that rely heavily on VATs export and import less as a fraction of GDP than do other countries, and the negative relationship between VATs and exports persists after controlling for observable variables." Similarly, Nicholson (2010) analyzes bilateral U.S. data for 146 countries by 29 sectors and 12 years and finds that VATs reduce exports. ${ }^{3}$ Similar results have been found by analyzing whether rebates on exports (a way to eliminate VATs on exports) can improve trade performance measures. Chandra and Long (2013) use firm-level Chinese data from 2000 to 2006 and find that a one percentage point increase in the average ETR rates raises the quantity of exports by $13 \% .{ }^{4}$ Gourdon et al. (2014) utilize HS6 product-level Chinese export volume data for

\footnotetext{
${ }^{3}$ Desai and Hines (2005) concluded that "the reasons that VATs impede international trade is that they tend to be imposed most heavily on traded sectors of economies, governments often fail to provide adequate VAT rebates for exports, VATs replace other taxes that may influence trade, and VATs encourage the growth of government."

${ }^{4}$ Also, see Chao et al. (2001), Chao et al. (2006), and Chen et al. (2006).
} 
a longer time period (from 2003 to 2012) and find a smaller but similar effect, i.e., a one percentage point increase in ETR rates leads to only a 7\% increase in export volume. ${ }^{5}$

We explore China as well, which acts as an interesting test case because the VAT system is not neutral. In addition, ETRs have fluctuated in China over time and are heterogeneous across industries. Our paper diverges from the previously mentioned studies by focusing on Chinese production allocation instead of export performance. This is an important distinction as misallocation can be an important factor reducing productivity in developing countries (e.g. Hsieh and Klenow (2009)). Therefore, aside from considering productive efficiency, there is room for policies to consider seriously the effect on allocative efficiency as well. We study a case where tax system treats exporters and non-exporters differently, ${ }^{6}$ which implies that there are idiosyncratic distortions. We tie this to the recent theoretical work on variable markups and allocative efficiency. As has been the case in trade studies that incorporate firm heterogeneity and variable markups, moments of the markup distribution provide an important avenue for research in the non-neutrality of the VAT rebate system, aside from export performance.

Our paper is also related to theoretical and empirical studies that highlight the linkages between trade policy and firm markups. Recent empirical work by De Loecker and Warzynski (2012) uses plant-level data from the Slovenian manufacturing industry and identifies the markup advantages of exporters relative to non-exporters. $\mathrm{Lu}$ and $\mathrm{Yu}$ (2015) find that markup variation increased increased in China after tariff reductions implemented in joining the WTO. In our paper we control for such events by using industry-year fixed effects in our firm level analysis to compare across rebate eligible and non-eligible within industries. A related theoretical work is that of Demidova and Rodríguez-Clare (2009) who study a small economy with distortions and find that trade policy has allocative efficiency implications through its effect on the markup distortion. Dalton and Goksel (2013) apply the model of Melitz and Ottaviano (2008) to closed economies, and show that higher taxes result in higher markups. Since rebates reduce taxes on exporters, our theoretical motivation is similar to their result. We are able to

\footnotetext{
${ }^{5}$ Gourdon et al.(2014) also finds a weak negative relationship between VAT rebate rate and unit price. They conclude that this weak negative impact of VAT rebates on unit price suggests that exporters largely absorb VAT rebate adjustments into their markups.

${ }^{6}$ Technically, not all exporters are rebate eligible, so we will differentiate firms as "eligible" vs "non-eligible" though also use exporters vs non-exporters since this is a close approximation. In the empirical section we detail how a firm is eligible for rebates.
} 
study the impact of such a tax on resource allocation by merging Chinese firm-level manufacturing data with customs transactions and tax information.

The paper proceeds in the following order. In section 2 we outline an extension of the Melitz and Ottaviano (2008) model that incorporates an export tax rebate. Section 3 describes the data to conduct the analysis and sections 4 and 5 contain the empirical specifications and results. Section 6 concludes.

\section{Model}

Our model builds on Melitz and Ottaviano (2008) (MO), with the addition of a tax rebate on exports. Therefore, the setup begins identical to $\mathrm{MO}$; later, the tax rebate is introduced into the firms' profit maximizing problem. We show that the rebate enters the firm's production decision and affects industry competition. Since this model fits qualitatively within the framework of Dhingra and Morrow (2014) (DM) and Arkolakis et al. (2015) (ACDR) with certain distributional assumptions, it allows us to tie our empirical analysis to the welfare and misallocation results described in these papers. ${ }^{7}$

\subsection{Closed economy}

Consider an economy with $L$ consumers, each consuming both traditional numeraire goods and manufactured goods and supplying one unit of labor. So, $L$ is also considered as the market size. The product of the manufacturing industry is horizontally differentiated in a continuum of varieties indexed by $i \in \Omega$. All consumers share the same utility function from Ottaviano, Tabushi, and Thisse (2002):

$U=q_{0}^{c}+\alpha \int_{i \in \Omega} q_{i}^{c} d i-\frac{1}{2} \gamma \int_{i \in \Omega}\left(q_{i}^{c}\right)^{2} d i-\frac{1}{2} \eta\left(\int_{i \in \Omega} q_{i}^{c} d i\right)^{2}$

where $q_{0}^{c}$ and $q_{i}^{c}$ represent the individual consumption levels of the numeraire good and each variety $i$ of the differentiated sector. ${ }^{8}$ The demand parameters $\alpha, \eta$, and $\gamma$ are all positive. The parameters $\alpha$ and $\eta$ index the substitution pattern between the differentiated varieties and the

\footnotetext{
${ }^{7} \mathrm{DM}$ and ACDR focus on the separable utility cases, which ignores the last term of the MO quadratic utility function. We stick with the MO non-separable case in the exposition, but the qualitative results for firm prices and production are the same if we eliminate the non-separable term. This term affects the competition entry and exit dynamics in the general equilibrium in response to changes in rebates.

${ }^{8}$ The separable cases of DM and ACDR eliminate the last term in Equation (1) ( $\left.\eta=0\right)$.
} 
numeraire, and $\gamma$ indexes the degree of product differentiation between the varieties. The inverted demand for each variety is given by:

$p_{i}=\alpha-\gamma q_{i}^{c}-\eta Q^{c}$,

where $Q^{c}=\int_{i \in \Omega} q_{i}^{c} d i$ is an aggregate consumption variable, and $p_{i}$ is the price of variety $i$. Let $\Omega^{*} \in \Omega$ be those varieties that are consumed; then (2) can be inverted to yield the linear market demand system for these varieties:

$q_{i} \equiv L q_{i}^{c}=\frac{\alpha L}{\eta N+\gamma}-\frac{L}{\gamma} p_{i}+\frac{\eta N}{\eta N+\gamma} \frac{L}{\gamma} \bar{p}, \forall i \in \Omega^{*}$

where $\bar{p}=\frac{1}{N} \int_{i \in \Omega^{*}}\left(\alpha-\gamma q_{i}^{c}-\eta Q^{c}\right) d i=\alpha-\frac{\gamma}{N} Q^{c}-\eta Q^{c}$, and $Q^{c}=\frac{\alpha-\bar{p}}{\frac{\gamma}{N}+\eta}$. Note that $N$ is the

(endogenous) measure of consumed varieties in $\Omega^{*}$ and $\bar{p}$ is their average price. The set $\Omega^{*}$ is the largest subset of $\Omega$ that satisfies:

$p_{i} \leq \frac{1}{\eta N+\gamma}(\gamma \alpha+\eta N \bar{p}) \equiv p_{\max }$.

In the equation above, the price bound $p_{\max }$ represents the price at which demand for a variety is driven to 0 . All else equal, a lower average price or a larger number of competing varieties $N$ induce a decrease in the price bound (where $p_{\max }<\alpha$, and therefore $\bar{p}<\alpha$ ).

\subsection{An open economy with export tax rebate}

Consider a world with two countries indexed by $\mathrm{H}$ and F. Assume that the governments of these countries adopt an export tax rebate (ETR) policy and let $t_{H}$ and $t_{F}$ denote the ETR rates. The countries may differ in three respects: market size $(L)$, trade cost ( $\tau$, ice-berg type), and ETR rate.

Let $p_{\max }^{l}$ denote the price threshold for positive demand in market $l(l=H, F)$, then (4) implies:

$p_{\max }^{l}=\frac{1}{\eta N^{l}+\gamma}\left(\gamma \alpha+\eta N^{l} \bar{p}^{l}\right), l=H, F$ 
where $N^{l}$ is the total number of domestic and foreign firms selling in country $l$, and $\bar{p}^{l}$ is the average price (across both local and exporting firms) in country $l$. The threshold of $p_{\max }^{l}$ will continue to hold under the ETR policy.

We can show that exporting firms' profits will be larger after receiving ETR from the government. Let $q_{X}^{l}(c)$ represent the export quantity of a firm's output with $\operatorname{cost} c$, and the delivered price will be $p_{X}^{l}(c)$. Under ETR policy, the profit in the export market of country $l$, and the profit maximizing prices and output levels, must satisfy

$$
\begin{gathered}
\pi_{X}^{H}(c)=\left[p_{X}^{H}(c)-\tau^{F} c\right] q_{X}^{H}(c)+t_{H} p_{X}^{H}(c) q_{X}^{H}(c) \\
p_{X}^{H}(c)=\frac{\tau^{F}}{2}\left(c_{X}^{H}+\frac{1}{1+t_{H}} c\right) \quad q_{X}^{H}(c)=\frac{L^{F}}{2 \gamma} \tau^{F}\left(c_{X}^{H}-\frac{1}{1+t_{H}} c\right), \\
\pi_{X}^{F}(c)=\left[p_{X}^{F}(c)-\tau^{H} c\right] q_{X}^{F}(c)+t_{F} p_{X}^{F}(c) q_{X}^{F}(c) \\
p_{X}^{F}(c)=\frac{\tau^{H}}{2}\left(c_{X}^{F}+\frac{1}{1+t_{F}} c\right) \quad q_{X}^{F}(c)=\frac{L^{H}}{2 \gamma} \tau^{H}\left(c_{X}^{F}-\frac{1}{1+t_{F}} c\right),
\end{gathered}
$$

where the delivered cost of a unit product with cost $\mathrm{c}$ to country $l(l=H, F)$ is $\tau^{l} c$, and $\tau^{l}>1$. When comparing the profit maximizing prices and quantities in the export market before and after the implementation of the ETR policy, the model predicts that exporting firms' export price falls and export quantity increases. Note, however, that only a partial amount of the rebate is passed through to prices. The profits of exporting firms increase because the negative effect of falling prices caused by ETR policy is less than the positive effect of increase in export scale.

Equations (6) and (7), and the effect on profits, will be tested in the differences-indifferences regression framework outlined in Section 4. Without entry and exit, these comparative statics have implications for the allocation of production among continuing firms as we outline in Section 2.4.1. However, in the next subsection we outline entry and exit in this model for completeness, and show that rebates could affect competition pressures for domestic and foreign sales. Therefore, in the empirical section we must account for these competitive pressures on prices and profits.

\subsection{Entry and Exit}


According to the open economy version of the MO model, only firms that earn non-negative profits in each segmented market (domestic or export) will choose to sell. Similarly, we can get the cost cut-off rules with the ETR policy. Let $c_{D}^{l}$ denote the upper bound cost for firms selling in their home market, $\pi_{D}^{l}(c)$ and $\pi_{X}^{l}(c)$ the profits earned in its domestic market and export market respectively, and $c_{X}^{l}$ the upper bound cost for exporters from $l$ to $h(l, h=H, F ; l \neq h)$. From MO, we know that these cut-offs summarize all effects of market conditions relevant to firm performance. Specifically, the maximized profit level can be rewritten as a function of firms' cut-off cost of entering each market as follows.

$$
\begin{aligned}
& \pi_{D}^{l}(c)=\frac{L^{l}}{4 \gamma}\left(c_{D}^{l}-c\right)^{2}, \\
& \pi_{X}^{H}(c)=\frac{L^{F}}{4 \gamma}\left(\tau^{F}\right)^{2}\left(1+t_{H}\right)\left(c_{X}^{H}-\frac{1}{1+t_{H}} c\right)^{2}, \\
& \pi_{X}^{F}(c)=\frac{L^{H}}{4 \gamma}\left(\tau^{H}\right)^{2}\left(1+t_{F}\right)\left(c_{X}^{F}-\frac{1}{1+t_{F}} c\right)^{2},
\end{aligned}
$$

As in $\mathrm{MO}$, there is no barrier to entry, but firms need to pay a sunk cost $f_{E}$, which they learn about only after making the irreversible investment required for entry. Free entry of domestic firms in country $l$ implies zero expected profits in equilibrium, and we have:

$$
\int_{0}^{c_{D}^{l_{D}}} \pi_{D}^{l}(c) d G(c)+\int_{0}^{c_{X}^{l}} \pi_{X}^{l}(c) d G(c)=f_{E}
$$

We assume the cost draws $c$ follow a Pareto distribution with the upper bound $c_{M}$ and shape parameter $k \geq 1$. The cost distribution will continue to hold under the new ETR policy. Using (6) and (7), the free entry conditions in both countries can be written as:

$$
\begin{aligned}
& L^{H}\left(c_{D}^{H}\right)^{k+2}+L^{F}\left(\tau^{F}\right)^{2}\left[\left(t_{H}+1\right)+\frac{k t_{H}\left(k t_{H}+3 t_{H}+2\right)}{2\left(t_{H}+1\right)}\right]\left(c_{X}^{H}\right)^{k+2}=\gamma \phi \\
& L^{F}\left(c_{D}^{F}\right)^{k+2}+L^{H}\left(\tau^{H}\right)^{2}\left[\left(t_{F}+1\right)+\frac{k t_{F}\left(k t_{F}+3 t_{F}+2\right)}{2\left(t_{F}+1\right)}\right]\left(c_{X}^{F}\right)^{k+2}=\gamma \phi
\end{aligned}
$$

where $\phi \equiv 2(k+1)(k+2)\left(c_{M}\right)^{k} f_{E}$ is a technology index. This free entry condition will hold so long as there is a positive mass of domestic entrants, $N_{E}^{l}>0$. We focus on the case that both 
countries produce a differentiated good and $N_{E}^{l}>0\left((l=H, F)\right.$. Since $c_{X}^{h}=c_{D}^{l} / \tau^{l}$, the free entry condition (11) can be rewritten as:

$$
\begin{aligned}
& L^{H}\left(c_{D}^{H}\right)^{k+2}+L^{F} \rho^{F}\left[\left(t_{H}+1\right)+\frac{k t_{H}\left(k t_{H}+3 t_{H}+2\right)}{2\left(t_{H}+1\right)}\right]\left(c_{D}^{F}\right)^{k+2}=\gamma \phi \\
& L^{F}\left(c_{D}^{F}\right)^{k+2}+L^{H} \rho^{H}\left[\left(t_{F}+1\right)+\frac{k t_{F}\left(k t_{F}+3 t_{F}+2\right)}{2\left(t_{F}+1\right)}\right]\left(c_{D}^{H}\right)^{k+2}=\gamma \phi
\end{aligned}
$$

where $\rho^{h} \equiv\left(\tau^{h}\right)^{-k} \in(0,1)$ is an inverse measure of trade costs (the "freeness" of trade).

According to this system for $(l=H, F)$, we can get the cut-off costs entering the domestic market in both countries.

$$
c_{D}^{H}=\left\{\frac{\gamma \phi}{L^{H}} \frac{1-\rho^{F}\left[\left(t_{H}+1\right)+\frac{k t_{H}\left(k t_{H}+3 t_{H}+2\right)}{2\left(t_{H}+1\right)}\right]}{1-\rho^{H} \rho^{F}\left[\left(t_{H}+1\right)+\frac{k t_{H}\left(k t_{H}+3 t_{H}+2\right)}{2\left(t_{H}+1\right)}\right]\left[\left(t_{F}+1\right)+\frac{k t_{F}\left(k t_{F}+3 t_{F}+2\right)}{2\left(t_{F}+1\right)}\right\}^{1 / k+2}}\right.
$$

Firms charge different markups in different markets based on the cut-off costs of entering these markets. Define a firm's markup in its home market as $\mu_{D}^{l}$, and $\mu_{x}^{l}$ as the markup that a firm charges in the foreign market. These are represented as:

$$
\begin{aligned}
& \mu_{D}^{l}=p_{D}(c)-c=\frac{1}{2}\left(c_{D}^{l}-c\right),(l=H, F) \\
& \mu_{X}^{l}=p_{X}(c)-\tau^{h} c=\frac{\tau^{h}}{2}\left(c_{X}^{l}+\frac{1}{1+t_{l}} c\right)-\tau^{h} c,(l, h=H, F)
\end{aligned}
$$

Then, the firm markup is positively related to the two cut-off costs.

Finally, to analyze whether the ETR rate has an impact on the cost cut-offs of entering a country's domestic market, we assume that trade costs are symmetric, $\rho^{L}=\rho^{H}$, and market size of both countries are the same, $L^{H}=L^{F}$. It is easy to show that when ETR for exporters are absent in both countries $\left(t_{H}=t_{F}=0\right)$, the model becomes identical to the open economy model of MO, where the cut-off cost of entering the domestic market is:

$$
c_{D}^{l}=\left(\frac{\gamma \phi}{L^{l}} \frac{1}{1+\rho}\right)^{\frac{1}{k+2}}, \quad(l=H, F)
$$

Now, let's consider the case we are interested in for this paper. 
Unilateral ETR policy: Only country $H$ implements ETR policy, and the ETR rate is $t_{H}$, thus $t_{F}=0$. The cut-offs in the home country is: ${ }^{9}$

$$
c_{D}^{H}=\left\{\frac{\gamma \phi}{L^{H}} \frac{1-\rho\left[\left(t_{H}+1\right)+\frac{k t_{H}\left(k t_{H}+3 t_{H}+2\right)}{2\left(t_{H}+1\right)}\right]}{1-\rho^{2}\left[\left(t_{H}+1\right)+\frac{k t_{H}\left(k t_{H}+3 t_{H}+2\right)}{2\left(t_{H}+1\right)}\right]}\right\}^{1 / k+2}
$$

For the case where both countries implement the same trade policy with equivalent ETR rates, $t_{H}=t_{F}=t$, see Appendix $\mathrm{B}$. Although the rebate policy is used by many countries in the world, the rebates tend to be constant over time. This has not been the case for China, which uses ETR policy as a mechanism for export promotion. Therefore, we measure the effects of changes in $t_{H}$ while assuming the policy in its trade partners does not change.

To simplify notation, let $\varphi=(t+1)+\frac{k t(k t+3 t+2)}{2(t+1)}, \varphi>1$, then given equations (13) and (14) and compared to the case that the government does not implement the ETR policy, the cut-off cost of entering country $H$ 's domestic market falls while the cut-off cost of entering country $H$ 's export market $\left(c_{X}^{H}=c_{D}^{F} / \tau^{F}\right)$ increases. ${ }^{10}$ Putting these together, the total number of entrants in country $H$ increases based on the relationship between the number of entrants and the cost cutoff in two markets. ${ }^{11}$ This implies tougher competition. According to the relationship between the firm markup and the two cut-off costs in country $H$, when only country $H$ implements an

${ }^{9}$ We assume $\frac{1-\rho\left[\left(t_{H}+1\right)+\frac{k t_{H}\left(k t_{H}+3 t_{H}+2\right)}{2\left(t_{H}+1\right)}\right]}{1-\rho^{2}\left[\left(t_{H}+1\right)+\frac{k t_{H}\left(k t_{H}+3 t_{H}+2\right)}{2\left(t_{H}+1\right)}\right]}>0$ to ensure $c_{D}^{H}>0$.

${ }^{10} \frac{\left(c_{D}^{H}\right)_{\text {without rebates }}}{\left(c_{D}^{H}\right)_{\text {unilateral rebates }}}=\left[\frac{1}{1+\rho} \frac{1-\rho^{2} \varphi}{1-\rho \varphi}\right]^{\frac{1}{k+2}}=\left[\frac{1+\rho \sqrt{\varphi}}{1+\rho} \frac{1-\rho \sqrt{\varphi}}{1-\rho \varphi}\right]^{\frac{1}{k+2}}$. Since $\varphi>1, \sqrt{\varphi}>1$, then $\varphi>\sqrt{\varphi}, 1+$ $\rho \sqrt{\varphi}>1+\rho$, and $\frac{1+\rho \sqrt{\varphi}}{1+\rho}>1$. For the second term, $1-\rho \sqrt{\varphi}>1-\rho \varphi$. This means that only if both sides are greater than zero then $\frac{1-\rho \sqrt{\varphi}}{1-\rho \varphi}>1$. On the other hand, if both terms are negative, the ratio is less than 1 .

Considering the actual trade climate (tax rebate about $15 \%$, trade costs of 1.8 , and $k=5$ ), it is innocuous to assume that $\frac{1-\rho \sqrt{\varphi}}{1-\rho \varphi}>1$, so that $\frac{1+\rho \sqrt{\varphi}}{1+\rho} \frac{1-\rho \sqrt{\varphi}}{1-\rho \varphi}>1$. Then: $\frac{\left(c_{D}^{H}\right)_{\text {withoutrebates }}}{\left(c_{D}^{H}\right)_{\text {unilateral rebates }}}>1$.

${ }^{11} N_{E}^{l}=\frac{2\left(c_{M}\right)^{k}(k+1) \gamma}{\eta\left(1-\rho^{l} \rho^{h}\right)}\left[\frac{\alpha-c_{D}^{l}}{\left(c_{D}^{l}\right)^{k+1}}-\rho^{l} \frac{\alpha-c_{D}^{h}}{\left(c_{D}^{h}\right)^{k+1}}\right]$. So, $N_{E}^{H}$ increases when $c_{D}^{H}$ falls and $c_{D}^{F}$ increases. 
export tax rebate policy (unilateral ETR), the change in the direction of exporters' markups is uncertain because the two cost cut-offs move in the opposite direction. This suggests that the ETR policy has an ambiguous effect on this size of exporters' markups when asymmetric policy is implemented. However, we can say that purely domestic firms will face tougher competition at home.

Finally, notice that the general equilibrium effect on competition requires the nonseparable term in Equation (1). As is stated in ACDR, using the additive utility case where $\eta=0$ would fix entry and therefore there would be no competition effects. ${ }^{12}$ In that case, the only result of a change in rebates is that eligible firms re-optimize their prices and production given the new rebates; this reallocates production across eligible and non-eligible firms.

\subsubsection{ETR Rate and Resource Misallocation}

In the analysis above we integrate ETRs into a general equilibrium model with heterogeneous firms and variable markups. Equations (6) and (8) show the direct effect on a firm's price, quantity, and profit from exporting, with respect to the ETR. Furthermore, equation (12) summarizes the indirect, general equilibrium effects that predict the level of competition in the domestic and export markets. This allows us to study the aggregate implications of China's ETR policy with a focus on its effect on allocative efficiency.

It has been known since Lerner (1934) that first-best efficiency is achieved only when markups are the same across products. Recent studies have applied this concept to heterogeneous firm trade models with variable markups. Dhingra and Morrow (2014) (DM) and Nocco et al. (2013) (NOS) both use variations of our linear demand model to derive market inefficiencies. ${ }^{13}$ The implication of those works - along with a related empirical result in Weinberger (2016) - is that markup dispersion lowers allocative efficiency. Dispersion in the markup distribution implies that some firms (those with low markups) produce too much and some firms (those with high markups) produce too little. This means that the reallocation of production that raises allocative efficiency, absent any entry/exit, allows production to move towards the initially high

\footnotetext{
${ }^{12}$ This requires that the productivity distribution is Pareto, as we assume above.

${ }^{13}$ NOS study market inefficiencies in the MO model. DM use a more general framework (of separable utility functions), but linear demand is a special case in that framework as long as the last term $\left(Q^{c}\right)$ in our preferences is eliminated.
} 
markup firms. This is seen in the theoretical result of ACDR, where the change in misallocation is equal to the covariance of changes in the firm-level labor share and price-cost markup. ${ }^{14}$

The distortions described above result from the demand side and are a market power distortion. Low-cost firms have more market power, and thus some of the cost difference is reflected in higher markups and lower quantity instead of lower prices. ${ }^{15}$ This insight regarding resource allocation is also present in the models of Hsieh and Klenow (2009) (HK) and Restuccia and Rogerson (2008), although in their models the same markup distortion can be explained with supply-side frictions. Whether the distortions are present in the demand side or supply side does matter for our interpretation of the inefficiency. In ACDR the inefficiency shows up in consumer welfare, while in HK it results in lower productivity. We interpret the heterogeneous markups as a market distortion, so that they can result in either type of inefficiency described above. In section 5 we define the misallocation measures used in the empirics.

The analysis above makes it clear that variation in export tax rebates will affect the allocation of production. Export tax rebates is incorporated into the pricing decision of exporters, who lower their price-cost ratio in response to a higher rebate. Since the reduction in price is proportionally less than the rebate received, export profits increase. Additionally, cost cut-offs - a sufficient statistic for competition at an aggregate level ${ }^{16}$ change in both the domestic and foreign market as shown above.

\subsubsection{ETRs and the Level of Competition}

We showed how the level of competition at the industry level will be affected by the ETR policy choice in Section 2.3. A rise in the export tax rebate increases competition in the domestic market and potentially reduces competition in the foreign market. Notice that exporters and nonexporters are affected differently, since only exporters are affected by export prices and export competition. ${ }^{17}$

\footnotetext{
${ }^{14}$ The intuition goes back to Basu and Fernald (2002), who argue that high markup firms represent varieties with high social value.

${ }^{15}$ Take for example two firms with costs, $\mathrm{c}^{\prime}<\mathrm{c}$, and prices $\mathrm{p}^{\prime}<\mathrm{p}$. Since $\frac{c^{\prime}}{c}<\frac{p^{\prime}}{p}$, then the low-cost firm is underproducing relative to the efficient allocation.

${ }^{16}$ We will consider four- and two-digit sectors.

${ }^{17}$ Our data will also count as "ineligible" export firms that do not receive rebates. We detail this distinction further in the empirical section.
} 
Markups of domestic producers and exporters with a unilateral ETR (country $H$ ) policy are:

$$
\begin{aligned}
& \text { Domestic Markups : } \mu_{D}^{H}(c)=\frac{1}{2}\left(c_{D}^{H}-c\right) \\
& \text { Export Markups : } \mu_{X}^{H}(c)=\frac{\tau^{F}}{2}\left(c_{X}^{H}+\frac{1}{1+t_{H}} c\right)-\tau^{F} c
\end{aligned}
$$

To investigate the influence of ETR policy on markup gap of the types of firms, we assume that both countries have the same market size, $L^{H}=L^{F}$, and trade costs are symmetric, $\tau^{H}=\tau^{F}$. Differentiating each equation with respect to the tax rebate yields:

$$
\begin{array}{r}
\frac{\partial \mu_{D}^{H}}{\partial t_{H}}=\frac{1}{2} \frac{\partial c_{D}^{H}}{\partial t_{H}} d t_{H} \\
\frac{\partial \mu_{X}^{H}}{\partial t_{H}}=\frac{\tau}{2}\left[\frac{\partial c_{X}^{H}}{\partial t_{H}} d t_{H}-\frac{c}{\left(1+t_{H}\right)^{2}} d t_{H}\right]
\end{array}
$$

If exporters produce both at home and abroad, then $\frac{\partial c_{D}^{H}}{\partial t_{H}}$ (predicted to be negative) and $\frac{\partial c_{X}^{H}}{\partial t_{H}}$ (predicted to be positive) both affect exporters and the overall effect is ambiguous. The change in their markups can also be driven by the direct effect of the rebate on prices (second term in the latter equation). According to Equation (6), prices decrease with the tax rebate.

In summary, it is hard to predict the markup effect on exporters. Domestic producers face a tougher environment as the domestic cut-off decreases in response to an increase in rebates. If the competition effect dominates the pass-through effect completely, then we would expect higher ETRs to result in lower markup for domestic firms relative to exporters. Since the passthrough effect lowers the markup of exporters, it is not possible to predict relative markup movements. In the empirical application, we examine the aggregate allocative efficiency using only incumbent firms, in order to eliminate the effects of changes in the cut-offs. In section 4.2, we will present the entry and exit dynamics occurring in China during this time.

\subsubsection{Allocative Efficiency Across Sectors}

Export tax rebates might affect not only the allocations of firms within sectors but also the allocation of production across sectors. This latter case is the intuition behind Epifani and Gancia 
(2011), which ignores intra-sector misallocation by assuming constant markups within a sector. ${ }^{18}$ In this case, average markups differ across sectors due for example to competition being heterogeneous across sectors. If some sectors are more competitive than others, they will have a lower than average markup and induce too much labor to be move to the sector and away from under-producing sectors. Whether allocation responses to ETR policy are felt mostly intra- or inter-sector depends on if the distributional effects are more pronounced between exporting and non-exporting firms within industries, or if industries themselves can be sorted as exporting and non-exporting, so rebates reallocate resources away from non-exporting industries and into exporting industries. Findings in the new trade literature that reflect ideas in the Melitz (2003) model give weight to the intra-sector distribution as all industries (at least at a more aggregate level) are made up of both exporting and non-exporting firms. We focus on this type of reallocation as well, as we do not find evidence of labor being reallocated across sectors in response to the rebate policy. The next section introduces our data and Section 4 investigates these distributional effects of the ETR policy in China.

\section{Data}

We use three data sets for the empirical analysis: all state-owned manufacturing firms and the above-scale (sales above 5 million Renminbi) private manufacturing firm panel data from the Chinese National Bureau of Statistics' (NBS) annual surveys (CASIF); Transactions-level trade data from China Customs (CCTS) that cover all transactions of Chinese exporters and importers; and export tax rebates rate from State Taxation Administration (EVATR). All data sets are from 2000 to 2006. The industries covered include CIC (Chinese Industry Classification) 13-42 with each firm being given a four-digit and two-digit classification. ${ }^{19}$ The CASIF data set contains the main balance sheet information, with more than 130 financial variables for each firm. The CCTS data set provides information on import and export values, quantities, destination at the HS eightdigit level for each trading firm. The EVATR data set records export tax rebates at the HS ten-

\footnotetext{
18 A similar argument is at play in oligopoly models, such as that of Peters (2011), where relative prices of products are distorted, and these prices caused by heterogeneous markups cannot reflect the scarcity of the respective commodity.

${ }^{19}$ The textile industry is not included in this data, which means the quota changes in 2005 should not affect our results.
} 
digit level. With information from the CCTS data set and EVATR, we calculate a firm's average ETR. As a note, we deflate all nominal values using 2000 as the base year.

Although this data set contains rich information, a few variables are noisy and misleading. We follow Cai and Liu (2009) and Feenstra et al. (2011) in cleaning the sample the following way: First, we drop all firms with less than eight employees, as they fall under a different legal regime. Then, we drop all firms with missing or negative key financial variables (such as total assets, net value of fixed assets, intermediate inputs, and total wages payable). Finally, we drop all firms with value of total fixed assets or value of total flowing assets outweighing value of total assets, and value of exports that outweigh gross value of industrial output. We merge the manufacturing firm data with the transaction level trade data using two methods from Yu and Tian (2012). First, we merge manufacturing firm data with the transaction level trade data based on firm names and data year. We interpret two firms to be the same one if they use the same firm name in the two data sets in the same year. Second, we merge the two data sets based on zip code and the last seven numbers of the firm phone number and drop all invalid samples (including zip codes are less than six numbers and phone numbers are less than seven numbers in the two data sets). After cleaning the sample, there are 1,304,636 observations. Export firms account for 396,422 and non-export firms 908,214 (close to 3/4 of the total number of observations). Table 1 reports statistics of the CASIF, CCTS, and merged data sets.

\subsection{Export Tax Rebates}

China began using ETRs in 1985. Since then, China has frequently adjusted the ETR rates, or, equivalently, the VAT refund levels, reducing the export rebates on more than 2,800 goods in 2007 alone (Casey and Murray, 2009). Prior to 2004, these adjustments were aimed mainly at increasing foreign exchange reserves and boosting the country's economic growth. After 2004, however, adjustments were intended to influence industrial structure and promote the balanced growth of imports and exports.

A firm's weighted average ETR rate equation is as follows:

$$
r e b_{-} f=\sum \frac{\text { value }_{H S 8}}{\text { value }} \times r e b_{H S 8},
$$

where value $_{H S 8}$ denotes the export value of each HS8 product exported by a firm, value denotes a firm's total export value, and $r e b_{H S 8}$ denotes the ETR rate of every HS8 product. Table 1 shows 
firms' average ETR rate over our data sample. The ETR rates are about 15\% from 2000-2003 but fell to under $13 \%$ in 2004 and beyond. ${ }^{20}$

Table 1 about here

We also compute the ratio of ETR rate divided by VAT rate as a measure of the tax on exports relative to refunding all VATs on exports. ${ }^{21}$ According to Gourdon et al. (2014), a complete rebate means the ETR rate that a firm gets from the government is equal to the VAT rate it pays in its production process. The firm receives closer to a complete rebate if this ratio is higher (it can be up to $100 \%$ ), and this situation is beneficial for export products to compete in the international market. We use a similar method to the one that computed the firms' weighted average ETR rate and compute the ETR to VAT ratio. Table 2 reports the results. Before 2003, the average value of this ratio is between $88.4 \%$ and $90.2 \%$, and decreases to 75.1\%-75\% between 2004 and 2006. Unsurprisingly, the patterns follow exactly from Table 1.

Table 2 about here

\section{Firm-level Empirical Specification and Results}

In order to test the predictions of the model, we specify and estimate the following equations by using trade and production data from CCTS and CASIF in China from 2000 to 2006. We start by using the firm data to produce markup and productivity estimates. Our data allows us to estimate markups using revenue-based production function, as in De Loecker and Warzynski (2012) and $\mathrm{Lu}$ and $\mathrm{Yu}(2015) .{ }^{22} \mathrm{We}$ also use other parts of the firm statistics, such as profits and production measures, to fully investigate the distributional effects between eligible and non-eligible firms.

\subsection{Production Function Results}

\footnotetext{
${ }^{20}$ Since the ETR policy was established in 1983, it has been adjusted many times. In 1995 and 1996, the zero rate for export products was adjusted to $3 \%, 6 \%$, and $9 \%$ (three different rates). Facing the Asian economic crisis in 1998 , the government increased the ETR rate of some products: to $5 \%, 13,15 \%$, and $17 \%$. On Jan. $1^{\text {st }} 2004$, in order to adjust the industry structure of exports and balance the economic development, the government adjusted the ETR rate to $5 \%, 8 \%, 11 \%, 13 \%$, and $17 \%$, and the average ETR rate decreased to below $13 \%$.

${ }^{21}$ A policy that many countries adopt.

${ }^{22}$ The latter also measure markup dispersion in China, although in their case they are interested in the effect of the WTO.
} 
Given the data in the Industrial Survey, we estimate markups as in De Loecker and Warzynski (DW, 2012). The estimation requires firms' revenue, labor input, capital stock, material input, and export behavior. To recover markups, the strategy is to first estimate production function coefficients using the method of Ackerberg et al. (ACF, 2006) with a Translog gross output production function. To control for the fact that production functions may be different for exporters and non-exporters, we include the lag of the export indicator as a state variable (see Kasahara and Rodrigue (2008)). The firm markup is the ratio of the materials' coefficient in the production function and materials' share of total input costs. The Translog specification allows us to recover both firm-specific material cost shares and material output shares. Additionally, we calculate firm TFP. Table 3 lists our results from estimating input coefficients at the two-digit industry level and the resulting markups. Note that for example the materials' coefficients are calculated as $\theta_{M}=\beta_{M}+2 \beta_{M M} M_{i t}+\beta_{L M} L_{i t}+\beta_{K M} K_{i t}+\beta_{L K M} L_{i t} K_{i t}$ due to the Translog specification. A similar calculation is done for labor and capital. Since the coefficients are firmspecific, we report the industry average, along with the median markup and the number of observations (these include firms more than once since it aggregates all years). The median markup ranges from 0.97-1.26, though most industries are around 1.10, within the range of estimates in the prior literature. ${ }^{23}$

\section{Table 3 about here}

\section{Section 4.2. Entry, Exit, and Competition}

The current literature on gains from trade has moved away from entry to some degree to concentrate on the effect of trade on incumbents. This is due to the use of the tractable Pareto distribution to describe the productivity distribution of firms. ${ }^{24}$ In examining the misallocation measures below we concentrate on the effect of ETRs on reallocation across incumbent firms, but we also want to check the competition effects that are present in the MO model.

Figure 1 plots the number of entrants and exiting firms for each year, where exit is defined as a firm not in the dataset in the next year. There are a couple of reasons for the seemingly huge entry jump in 2004. Brandt et al. (2012) point out that many private firms were left out before

\footnotetext{
${ }^{23}$ Of course 0.97 would not be a possible markup in our model, though this is just one industry and likely due to measurement error.

${ }^{24}$ Arkolakis (2015) is one of the better-known examples. See Feenstra (2014) for a way to reintroduce entry into trade models.
} 
2004 simply due to the identification of firms by the census. Moreover, Bai et al. (2015) point out that export licenses made it very difficult for private firms to export directly before 2004, with preference given to foreign and state-owned enterprises. This makes it difficult to study the effects of ETR on competition.

An interesting observation is that firms that exit the next year tend to have higher markups. The median markup of exiting firms is 1.171 across all years, compared to the median of 1.158 for the whole sample. The entry of private firms most likely led to increasing departures of older and state-owned firms with high markups. On the other hand, entrants have lower markups than both incumbents and exiting firms. Markup distributions for the 3 types of firms are shown in Figure 2. Therefore, aside from the effect of ETRs, there is most likely tougher competition in the export market after 2003. Overall, markups were higher in the second half of the time period as seen in Figure 3. Domestic competition therefore seems less tough overall in the domestic market.

\subsubsection{Specification: How Rebates Affect Eligible Firms}

We confirm that an increase in the rebate does have the distributional implications between eligible and non-eligible firms, as predicted by our model with heterogeneous firms and incomplete pass-through of costs to prices. To do so, we will first calculate the price and quantity response to changes in rebates for eligible firms. We then compare the effect of a change in ETR policy on eligible firms (the treated group directly affected by a change in tax rebates) to non-eligible firms using a difference-in-difference specification. The eligibility definition is straightforward, as a firm must be an exporter and additionally it cannot be a "processing trade with supplied materials" type. The latter characteristic is used to characterize non-eligibility in Gourdon et al. (2014), but they use aggregate (HS6) data while we use transaction-level data and then aggregate to the firm-level; therefore, we can identify firms that are both exporters and non-processing firms.

In Equation (6), we find that prices are reduced and quantity increases in response to a higher rebate rate. Profits increase because a fraction of the rebate is passed through to markups, but the price still falls and the markup over marginal cost is reduced. Although we can only construct markups and profits at the firm level where we have financial variables, export prices and quantities are available from customs transactions. We will check the predictions of 
Equation (6) using the customs transaction level data that provides exports at the destinationHS8-firm level. The following specification applies to firms that are eligible for rebates:

$$
y_{i p t}=\alpha+\delta r v_{-} f_{i p t}+\beta X_{i t}+\gamma_{i p}+\gamma_{t}+u_{i p t}
$$

where $y_{i p t}$ is the outcome variable (prices and quantities) at the firm (i)- HS8 product (p)-year (t) level. The fraction of VAT taxes rebated back to the firm is $r v_{-} f_{i p t}$, which is described in Section 3.1. $X_{i p t}$ are firm and product characteristics such as capital/labor ratio, foreign ownership share, and HS6 product tariff rates. Firm-product fixed effects $\left(\gamma_{i p}\right)$ allow us to test the effect changes in the rebates within firm-product transactions and we also add year fixed effects. $^{25}$

\subsubsection{Specification: Difference-in-difference}

We will also use a difference-in-difference specification to compare the outcome differences between eligible and non-eligible firms for the rebate before and after a policy change. To identify the result of the policy, we compare the effect on the treatment group with the effect on a control group that we believe should not change their production for reasons other than competition effects. We concentrate on the interaction $\{$ Year $\geq 2004 *$ Eligible $\}$ because there is a large policy variation in 2004 and beyond relative to the pre-2004 period. ${ }^{26}$ We use this specification mostly at the firm level where firms are either eligible or not eligible for rebates, which includes mostly exporters versus non-exporters. At that aggregation we have to use total value of exports, average rebate, and the financial variables in the CASIF data.

The regression specification is:

$\mu_{i j t}=\alpha+\rho \mu_{i j t-1}+\delta\left\{\geq 2004 *\right.$ Eligible $_{i j t}+\beta \omega_{i j t}+\rho X_{i j t}+\gamma_{j t}+u_{i j t}$,

where the coefficient of interest is $\delta$, and we also include " $>=2004$ " and "Eligible" in the regression individually (though not shown above). We add industry-year fixed effects $\left(\gamma_{j t}\right)$ in order to compare across eligible and non-eligible firms within an industry-year observation and

\footnotetext{
${ }^{25}$ We could use firm-product-destination transactions instead, since the current specification necessitates aggregating the destination transactions to the product level. However, the results are essentially identical and we use the current specification since rebates are at the product level.

${ }^{26}$ Tables 1 and 2 report that export tax rebates were reduced to be significantly more incomplete (only around $75 \%$, down from $90 \%$ ).
} 
control for the large macroeconomic shocks hitting China at this time. $\mu_{i j t}$ represents the outcome variable, for example the firm (i) in markup, where $j$ is the four-digit CIC industry classification of the firm. We include the lagged outcome variable to control for autocorrelation of firm variables and use $\omega_{i j t}$ to represent the firm revenue TFP residual, using the specification of Ackerberg et al. (2006) since that will be a common control variable. Additionally, we interact the " $\geq 2004$ " variable with tariffs to control for the effect of tariffs during this policy variation. Finally, we control for other firm and industry characteristics such as capital/labor ratio, market share concentration (HHI), tariffs, firm age, an importer dummy, foreign ownership share, and province dummy variables.

\subsection{Results}

Table 4 includes the results from exporting firms only and uses the specifications shown in both Equations (14) and (15). The first two columns simply regress firm-product level quantity and price respectively on the proportion of VAT taxes that are rebates using the firm-product fixed effects specification. There is strong evidence that a higher rebate pushes up the quantity produced of that product. An increase of 0.1 in the rate of the VAT rebated leads to an almost $3 \%$ increase in quantity. In Table 2 we show that the average fraction of VAT rebated decreases about 15 percentage points in 2004, making the potential effect on quantities exported economically significant. The second column shows that the sign for the effect of rebates on prices is correct but not significant, which could be because there is very little actual passthrough of the rebate to prices. This result is consistent with studies that have found very small short-term pass-through of costs to prices, and the rejection of constant pass-through models.

The last four columns compare eligible exporters to non-eligible (processing) exporters. ${ }^{27}$ We use two separate diff-in-diff specifications: comparing eligible to non-eligible post-2004 (as in Equation (14)) and also interacting the eligible dummy with the actual rebate rate for that sector. The latter diff-in-diff is shown in columns (3) and (5), which provides evidence that at higher rebates, eligible firms produce relatively higher quantity and lower prices than noneligible firms. These are therefore consistent with Equation (6). Columns (4) and (6) use the "post-2004" specification and finds that eligible firms raise their prices relative to non-eligible

\footnotetext{
${ }^{27}$ In this case, there are many more eligible observations than non-eligible since most exporters are eligible.
} 
firms after rebates are reduced in all industries in 2004-2006. However, the quantity variable implies that eligible firms also raised their quantity after the rebate decline, though this result is not significant. Overall, the results do support the prediction that higher rebates lead to more production and slightly lower prices for eligible firms.

\section{Table 4 about here}

The next set of results aggregate to the firm level by matching the CASIF financial variables to the customs and export tax datasets. We now have firm-year observations for both exporters and non-exporters, but the export transactions have to be aggregated across destinations and products, with firms classified into four-digit CIC industries. We can produce the TFP and markup estimates using firm revenue and input data. To examine the effect of tax rebates we continue to consider exporters that are not "processing with supplied materials" as eligible, and use all other firms (mostly non-exporters) as the non-eligible control group.

Table 5 runs the specification in Equation (15) for many different outcome variables. We are interested in the interaction in the fourth row, though we show some of the other regressors as well. All regressions include the lagged outcome variable but are omitted from the table for brevity. The regular markup is estimated using the De Loecker and Warzynski (2012) method as previously covered, but we also try a simpler measure of $\mu(P C M)=\frac{V A-\text { wages }}{V A+\text { inputs }}$, and refer to it as "markup (PCM)". ${ }^{28}$

The first column is consistent with expectation that eligible firms have higher markups pre-2004 (third row), but the difference between the two becomes smaller after the rebate reduction. The results hold up with the alternative markup measure in the second column. Although this is inconsistent with the results in Table 4 and the model predictions, we do see that profits are reduced for eligible firms as would be expected given the decrease in the rebate (third column). Relative to non-eligible firms, eligible firms' profits rise $0.5 \%$ and revenues $4.4 \%$ in 2004 and beyond. It is also clearly the case that eligible firms buy less labor and materials relative to non-eligible firms after the rebates are reduced in 2004. The last column shows that the lower markup difference seems driven by eligible firms having a relatively higher material share in revenue after the policy change (which is our proxy for costs), as revenues and labor

\footnotetext{
${ }^{28}$ This measure goes all the way back to Kalecki (1971).
} 
both decrease in rebate-eligible firms. The penultimate column is evidence that there is a reallocation of labor out of eligible firms after the rebate is reduced. The markup results suggest that the pass-through of the rebates to prices is very low and most of the effect is through reallocation of production.

\section{Table 5 about here}

The distributional results from Table 5 therefore point to a reallocation of production due to policy variation in export rebates. A reduction in the proportion of the VAT that is rebated to eligible firms shifts production relatively more to non-eligible firms. To check the robustness of the results, we estimate a similar regression specification where we replace the 2004 variable with the average industry rebate; this is illustrated in Appendix A. The interaction term of the average rebate with eligible firms mostly has the opposite sign as in Table 5, which is consistent with the fact that the 2004 variable proxies a lower average rebate. The implication for allocative efficiency depends on aggregate results, to which we turn to in Section 5.

\section{Aggregate Measures of Misallocation}

The distributional results above imply a reallocation of production towards eligible firms when rebates increase. Whether this increases allocative efficiency depends on if these eligible firms were over-producing or under-producing before the policy variation. In the MO model, underproduction is represented by a higher markup, which also means that other firms are overproducing. Furthermore, if we were to add supply-side distortions as in Hsieh and Klenow (2009) (HK), then under-production would be represented by a firm with high revenue productivity (we call this measure TFPR as in HK). ${ }^{29}$

There are therefore two possible second-order moments to use. First, dispersion measures of both markups and revenue TFP are associated with misallocation. In the MO model, allocative efficiency is achieved when the distribution of markups is degenerate, and in the HK model efficiency is achieved when the TFPR dispersion is degenerate. In summary, higher dispersions of markups and TFPR are evidence of higher misallocation.

\footnotetext{
${ }^{29}$ TFPR is a combination of residual productivity and output prices.
} 
Second, we will examine the covariance of changes in the market share and markups/TFPR. Using the intuition of over and under production, it is intuitive that in the MO model allocative efficiency increases when market share increases relatively more for highmarkup firms. ${ }^{30}$ In the HK model, high TFPR firms are under-producing, and thus aggregate TFP increases when market share is driven to high TFPR firms. Therefore, a positive growth in these covariance measures is related to lower misallocation.

The change in misallocation is driven by the micro-level reallocations, specifically whether the VAT on exporters is distortive. As the share of the VAT that is rebated gets closer to "complete" - or Equation (13) divided by VAT rate approaches 100\% - this distortion is eliminated. We check whether the reallocation to eligible firms leads to lower dispersion measures and higher covariance measures.

To measure industry-wide allocations we aggregate the data using the ASI classifications which are at four-digit CIC codes. We group firms within these industry categories and calculate the averages and dispersions of industry aggregates. The first specification will be to run a regression of rebates on the second order outcome measures:

$$
\operatorname{var}\left(\mu_{j t}\right)=\alpha+\delta r v_{-} f_{j t}+\beta X_{j t}+\gamma_{j}+\gamma_{t}+u_{j t}
$$

where $j$ and $t$ denote industry and years, respectively, and $r v_{-} f_{j t}$ is the average of the proportion of the VAT tax that is rebated to eligible firms in an industry-year. The main coefficient of interest is $\delta$, which corresponds to the effect of the "completeness" of the rebate on the outcomes variables which include the two dispersion measures and the two covariance measures. Rebates are the average for eligible firms in each industry and we also create industry controls that can be averages or dispersions. We include separate year and industry fixed effects. The outcome variable includes the markups and TFPR dispersions, plus the covariance of one-year changes in firm market share with markup/TFPR. Since the unit of observation is industry-year, each of these statistics uses firm data within an industry-year. Also notice that these must be affected only by incumbent firms.

The second specification to test for the effects of taxes/rebates on resource misallocation is again a difference-in-difference using the year of the policy variation:

$$
\operatorname{var}\left(\mu_{j t}\right)=\alpha+\delta\{\geq 2004 * \text { Share }\}_{j t}+\beta X_{j t}+\gamma_{j}+\gamma_{t}+u_{j t} .
$$

\footnotetext{
${ }^{30}$ See Arokolakis et al. (2015) and Weinberger (2016).
} 
The interaction term is the policy variation (2004 and beyond) with a share variable that proxies how exposed an industry is to the rebate change. We use the share of firms that are eligible in industry $j$, and also check the results with a measure of the export intensity of the industry (which we do not include here). We once again control for additional covariates: for example the TFP dispersion $\left(\operatorname{var}(\omega)_{j t}\right)$ when the markup dispersion is the outcome variable, and we add an average of the outcome variable in all regressions. Additional controls also include industry capital/labor ratios, market concentration, tariffs, import intensities, average foreign ownership, and year plus industry fixed effects. The outcome variables are again both dispersion and covariance measures.

Table 6 displays results of the policy variation on the dispersions and covariances, with most of the evidence pointing towards lower misallocation when VATs are more fully rebated. There is a very significant reduction in the markup dispersion, while the TFP dispersion is also lower with significance at the $11 \%$ level. The covariance measures are less robust, however. In the last column we show that the TFPR-change in market share covariance is positive, evidence towards firms with initially high TFPR gaining market share in response to higher rebate levels. However, we find the opposite sign for the markup-change in market share covariance, which is evidence of high markup firms losing market share and lower allocative efficiency. This is surprising since TFPR and markups are correlated at the firm level, but it could be related to our prior result in Table 5. There is reallocation to more productive firms, but these firms don't necessarily have higher markups, which is, for example, consistent with the large exit of old, high-markup firms. We will see in the next Table that this covariance becomes insignificant.

Table 6 about here

Table 7 compares industries across the spectrum of how exposed they are to the rebate change. The results are consistent with the expectation that the policy change of reducing rebates raises the standard deviation of markups and TFPR relatively more in industries that are exposed to the rebate policy (through a high share of eligible). The first four columns use the interaction of "eligible share" and "2004 and beyond." Once again, the dispersion of markups and TFPR, plus the TFPR-market share, change covariance move in the expected way. Industries with more eligible firms become relatively more misallocated as a result of the lower rebates; this is shown 
by the reduction in the covariance and higher dispersions. The markup-market share covariance is insignificant. ${ }^{31}$

\section{Table 7 about here}

In summary, the evidence points towards an increase in misallocation after 2004 in industries that had more rebate-eligible firms. The most robust results are in the second moments of the TFPR distributions, where we consistently see both the dispersion of TFPR and the covariance of TFPR with market share changes point towards this conclusion. This is consistent with the misallocation described in the HK model, where taxes on exports act as a distortion. However, due to the firm-level results and changes in the markup dispersions, we believe a demand-side model, as in MO, also does a satisfactory job of illustrating the effects of the tax rebate on the allocation of production.

\section{Conclusions}

The export tax rebate policy has been one of the most common instruments utilized by Chinese policy makers. How does this policy affect Chinese firms' markup rates and distort allocation of resources between its exporting and non-exporting firms? In this study, we provide answers to these questions. To accomplish this, we first build on the Melitz and Ottaviano (2008) model to provide predictions about differential impact of ETRs on exporting and non-exporting firms. We then empirically examine the model's predictions regarding the impact of ETRs on firms' production decisions and resource allocation between exporting and non-exporting firms by utilizing a rich firm-level production, customs, and tax data.

Our study first shows that an increase in rebates results in higher quantities produced, lower output prices, and higher profits for the firms that are eligible for the rebates. To explore the distributional effects, we then examine the effects of change in rebate policy on the reallocation of production between eligible and non-eligible firms for the tax rebates. The results from a difference-in-difference specification show that an increase in tax rebates leads to more production by eligible firms compared to non-eligible ones.

\footnotetext{
${ }^{31}$ In the Appendix Table 2A we include a similar regression with an interaction of share of eligible firms with the level of the rebate at the industry level. The results are qualitatively similar, although the markup dispersion results become insignificant.
} 
We then aggregate the data to the industry level and find that the markup and revenue productivity dispersions both decrease with a higher rebate of VATs for exporters, consistent with expectation that allocative efficiency is likely to rise in response to an increase in rebates. We also explore the covariance of market share and markups plus TFPR to check whether the observed reallocation is consistent with the dispersion results. We are able to verify that better allocative efficiency is indeed consistent with the market share moving to higher TFPR firms, as in the Hsieh and Klenow (2009) model. We do not find the expected covariance sign consistent with the Arkolakis et al. (2015) model; however, this is likely due to the difficulty in measuring firm level markups.

\section{References}

Ackerberg D., F. Caves, and G. Frazer (2006). "Structural Identification of Production Functions." MPRA Working Paper 38349.

Arkolakis C., A. Costinot, D. Donaldson, and A. Rodriguez-Clare (2015). "Elusive ProCompetitive Effects of Trade." NBER Working Paper No. 21370.

Bai X., K. Krishna, and H. Ma (2015). "How You Export Matters: Export Mode, Learning and Productivity in China." NBER Working Paper 21164.

Basu S. and Fernald, J. (2002). "Aggregate Productivity and Aggregate Technology." European Economic Review, Vol. 46, 963-991.

Brandt L., J. Van Biesebroeck, and Y. Zhang (2012). "Creative Accounting or Creative Destruction? Firm-level Productivity Growth in Chinese Manufacturing." Journal of Development Economics, vol. 97, 339-351.

Cai, H. and Liu, Q. (2009). "Competition and Corporate Tax Avoidance: Evidence from Chinese Industrial Firms.” The Economic Journal, Vol.119, 764-795.

Casey, W. and M. Murray (2009). “Import and Export Price Trends, 2007.” Monthly Labor Review (BLS), Vol.132, 15-27.

Chandra, P. and C. Long (2013). "VAT Rebates and Export Performance in China: Firm-Level Evidence." Journal of Public Economics, Vol.102, 13-22.

Chao, C., W. L. Chou, and S.H. Yu (2001) " Export Duty Rebates and Export Performance: Theory and China's Experience.” Journal of Comparative Economic, Vol.29, 314-326.

Chao, C., E. Yu and W. Yu. (2006). "China's Import Duty Drawback and VAT Rebate Policies:A General Equilibrium Analysis." China Economic Review, Vol.17,432-448. 
Chen, C. H., C.C. Mai, and H. C. Yu (2006) "The Effect of Export Tax Rebates on Export Performance: Theory and Evidence from China." China Economic Review, Vol.17, 226-235.

Dalton, J. T. and T. Goksel (2013). "Firm Taxation and the Endogenous Distribution of Markups.” Economics Letters, Vol.121, No.3., 520-523.

De Loecker, J., Goldberg, P., Khandelwal, A., and N. Pavcnik (2015). "Prices, Markups and Trade Reform." Econometrica, Forthcoming.

De Loecker, J. and F. Warzynski (2012). "Markups and Firm-Level Export Status.” American Economic Review, Vol.102, No.6., 2437-2471.

De Loecker, J., (2007). "Do Export Generate Higher Productivity? Evidence from Slovenia." Journal of International Economics, Vol.73, 69-98.

Demidova S. and A. Rodríguez-Clare (2009). "Trade Policy under Firm-level Heterogeneity in A Small Economy.” Journal of International Economics, Vol.78, 100-112.

Desai, M. and Hines, J.R. (2005). "Value-Added Taxes and International Trade: the Evidence." March 2005, mimeo.

Dhingra, S. and L. Morrow (2014). "Monopolistic Competition and Optimum Product Diversity under Firm Heterogeneity.” Working Paper.

Epifani, P. and G. Gancia (2011). “Trade, Markup Heterogeneity, and Misallocation.” Journal of International Economics, Vol. 83, 1-13.

Feldstein M., Krugman, P. (1990) "International Trade Effects of Value-added Taxation in Razin and Slemrod", Working Papers, NBER.

Feenstra, R.C. (2014). "Restoring the Product Variety and Pro-Competitive Gains from Trade with Heterogeneous Firms and Bounded Productivity.” NBER Working Paper No. 19833.

Feenstra R.C., Li Z. Y., and Yu M. J. (2011). “ Exports and Credit Constraints Under Incomplete Information: Theory and Evidence from China”, NBER Working Paper No. 16940.

Gourdon J., Hering L., Monjon S. and Poncet S. (2014) "Using VAT Rebates to Promote Exports: Evidence from China during the Global Crisis.” Working Paper.

Hsieh, C. and P. Klenow (2009). "Misallocation and Manufacturing TFP in China and India." Quartlerly Journal of Economics, Vol.124, No.4, 1403-1448.

Kalecki, M. (1971). "Class Struggle and the Distribution of National Income.” Kyklos, Vol. 24, $1-9$. 
Kasahara, H. and J. Rodrigue (2008). "Does the Use of Imported Intermediates Improve Productivity? Plant-level Evidence.” Journal of Development Economics 87 (1), 106-118.

Lerner, A., (1934) "The Concept of Monopoly and the Measurement of Monopoly Power." Review of Economic Studies, 1, 157-175.

Lu, Y. and L. Yu (2015). "Trade Liberalization and Markup Dispersion: Evidence from China's WTO Accession." American Economic Journal: Applied Economics, Vol. 7, No. 4, 221-253.

Melitz, M. J. and Ottaviano, G. I. P. (2008). "Market Size, Trade, and Productivity." Review of Economic studies, Vol. 75, 295-316.

Nicholson, M. (2010). "Value-Added Taxes and U.S. Trade Competitiveness.” FREIT Working Papers no. 186.

Nocco, A., Ottaviano, G., and M. Salto (2013). "Monopolistic Competition and Optimum Product Selection: Why and How Heterogeneity Matters.” CEP Discussion Paper No. 1206.

Ottaviano, G. I. P., T. Tabuchi and J-F. Thisse (2002). "Agglomeration and Trade Revisited", International Economic Review, Vol. 43, 409-436.

Olley, G. and A. Pakes (1996). "The Dynamics of Productivity in the Telecommunications Equipment Industry.” Econometrica, Vol. 64, 1263-1297.

Peters, M., (2011). “Heterogeneous Mark-Ups and Endogenous Misallocation.” MIT Working Paper.

Restuccia, D. and R. Rogerson (2008). "Policy Distortions and Aggregate Productivity with Heterogeneous Plants.” Review of Economic Dynamics, Vol. 11 (4), 707-720.

Weinberger, A. (2016). "Markups and Misallocation with Trade and Heterogeneous Firms." Working Paper.

Yu, M. and Tian, W. (2012). “China's Firm-level Processing Trade: Trends, Characteristics and Productivity.” Available at SSRN http://ssrn.com/abstract=2037827. 


\section{FIGURES:}

Figure 1. Number of Entry and Exit per Year

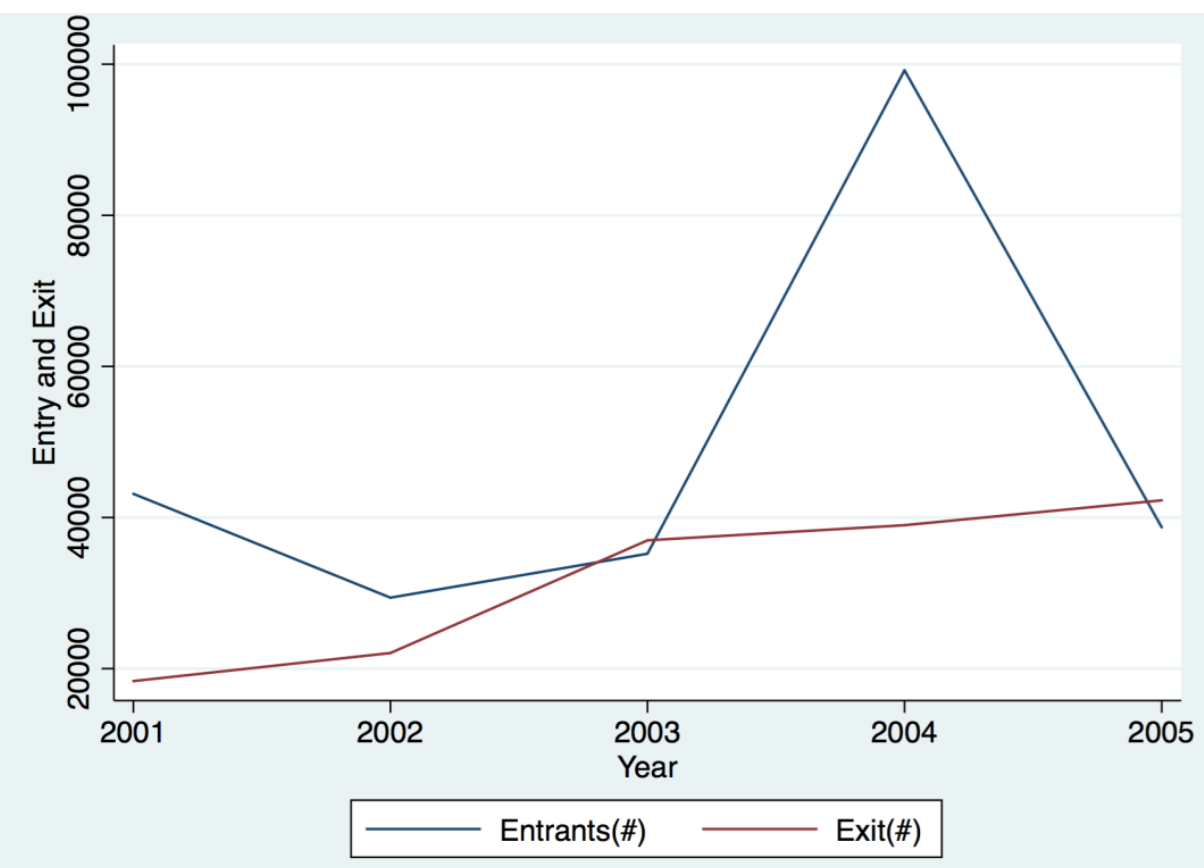

Figure 2. Kernel Density: Incumbents, Entrants, and Exiting Firms

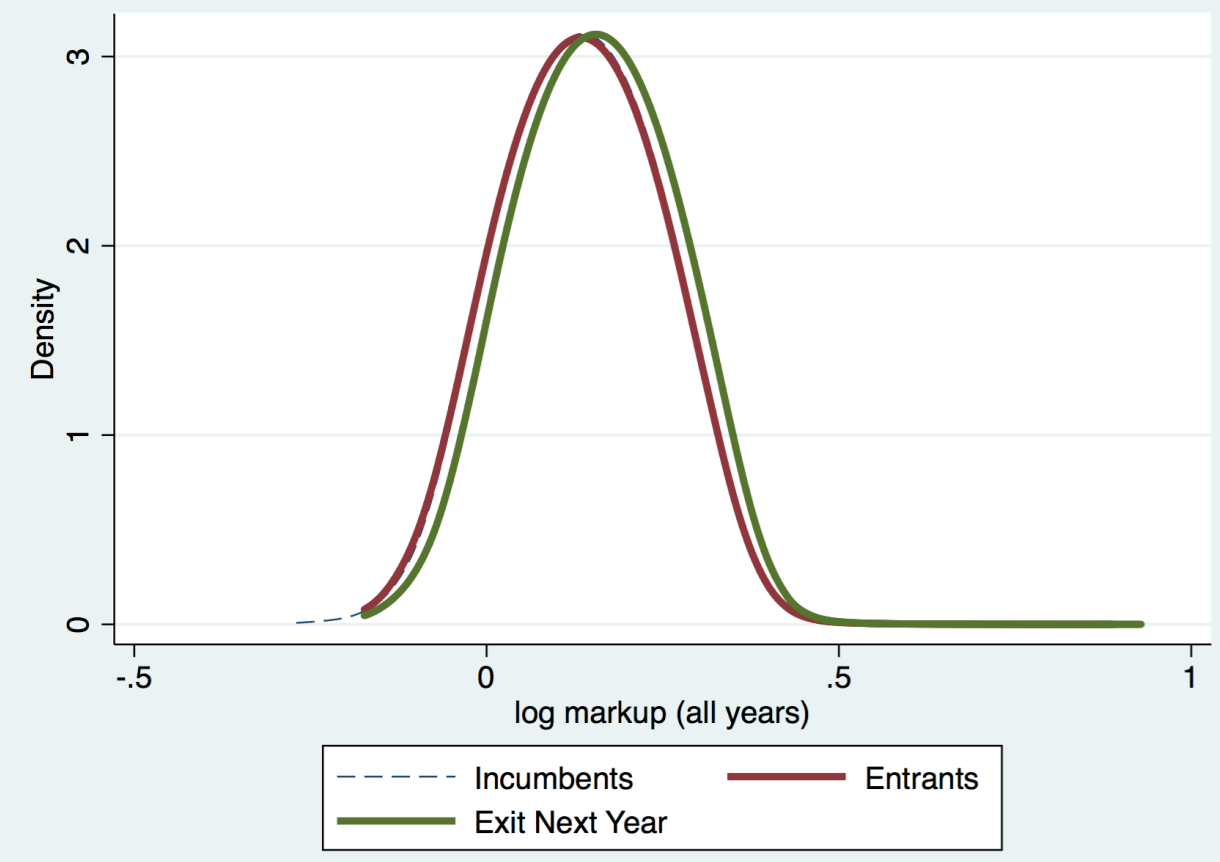


Figure 3. Log Markup Distribution of Exporters Pre- and Post-2004.

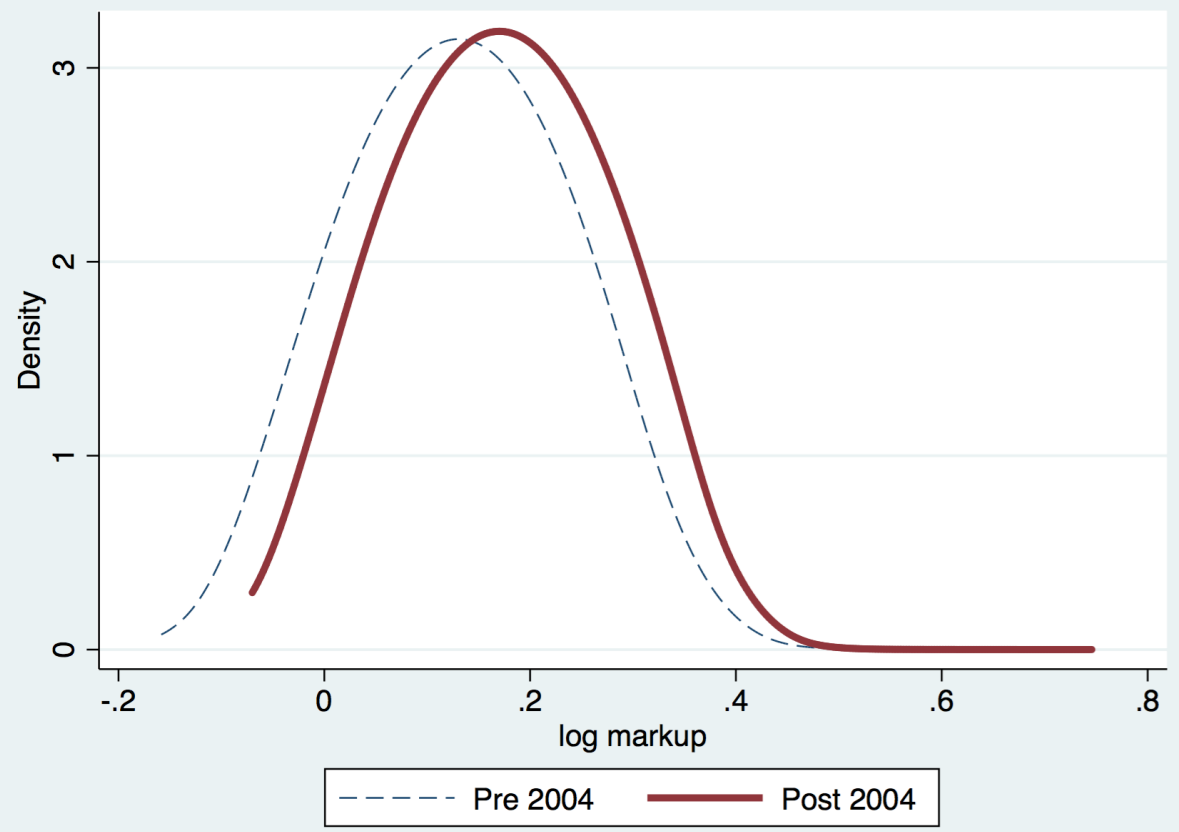


TABLES:

Table 1. Firm ETR rate 2000-2006

\begin{tabular}{|c|c|c|c|c|c|}
\hline Year & Observations & Mean & $\begin{array}{c}\text { Standard } \\
\text { Deviation }\end{array}$ & Min & Max \\
\hline 2000 & 19047 & 0.1494 & 0.0238 & 0 & 0.17 \\
\hline 2001 & 21360 & 0.1518 & 0.0220 & 0 & 0.17 \\
\hline 2002 & 22085 & 0.1524 & 0.0218 & 0 & 0.17 \\
\hline 2003 & 21296 & 0.1509 & 0.0234 & 0 & 0.17 \\
\hline 2004 & 36133 & 0.1274 & 0.0181 & 0 & 0.17 \\
\hline 2005 & 42547 & 0.1282 & 0.0188 & 0 & 0.17 \\
\hline 2006 & 24610 & 0.1288 & 0.0167 & 0 & 0.17 \\
\hline
\end{tabular}

Notes: Firm ETR rate is as defined in $r e b_{-} f$ in the main text.

Table 2. Ratio of ETR rate to VAT rate

\begin{tabular}{|c|c|c|c|c|c|}
\hline Year & Observations & Mean & $\begin{array}{c}\text { Standard } \\
\text { Deviation }\end{array}$ & Min & Max \\
\hline 2000 & 19054 & 0.8842 & 0.1296 & 0 & 1 \\
\hline 2001 & 21361 & 0.8980 & 0.1188 & 0 & 1 \\
\hline 2002 & 22087 & 0.9017 & 0.1186 & 0 & 1 \\
\hline 2003 & 21303 & 0.8928 & 0.1275 & 0 & 1 \\
\hline 2004 & 36275 & 0.7513 & 0.1070 & 0 & 1 \\
\hline 2005 & 42842 & 0.7521 & 0.1170 & 0 & 1 \\
\hline 2006 & 24912 & 0.7505 & 0.1228 & 0 & 1 \\
\hline
\end{tabular}

Notes: Ratio is defined as firm ETR rate divided by VAT rate. We then take the mean and standard deviation across all eligible firms in each year. 
Table 3. Output Coefficients and Markups by 2-digit Industry

\begin{tabular}{|c|c|c|c|c|c|}
\hline & $\mathrm{N}$ & Labor Coeff & Capital Coeff & Mat. Coeff & Med. Markup \\
\hline 13 & 61875 & 0.06 & 0.01 & 0.88 & 1.14 \\
\hline 14 & 29946 & -0.00 & 0.02 & 0.96 & 1.25 \\
\hline 15 & 18337 & 0.17 & 0.07 & 0.72 & 0.97 \\
\hline 16 & 1035 & 0.41 & 0.08 & 0.74 & 1.16 \\
\hline 17 & 84353 & 0.05 & 0.02 & 0.90 & 1.15 \\
\hline 18 & 39344 & 0.12 & 0.02 & 0.85 & 1.12 \\
\hline 19 & 19918 & 0.07 & 0.01 & 0.92 & 1.18 \\
\hline 20 & 23204 & 0.03 & 0.02 & 0.93 & 1.21 \\
\hline 21 & 11328 & 0.04 & 0.01 & 0.96 & 1.24 \\
\hline 22 & 37207 & 0.03 & 0.01 & 0.95 & 1.21 \\
\hline 23 & 25131 & 0.05 & 0.03 & 0.93 & 1.24 \\
\hline 24 & 10344 & 0.08 & 0.02 & 0.90 & 1.16 \\
\hline 25 & 8959 & 0.03 & 0.01 & 0.94 & 1.21 \\
\hline 26 & 82632 & 0.04 & 0.03 & 0.89 & 1.14 \\
\hline 27 & 23151 & 0.07 & 0.03 & 0.90 & 1.18 \\
\hline 28 & 6195 & 0.03 & 0.00 & 0.95 & 1.16 \\
\hline 29 & 12857 & 0.05 & 0.02 & 0.90 & 1.17 \\
\hline 30 & 51187 & 0.10 & 0.04 & 0.83 & 1.05 \\
\hline 31 & 99238 & 0.04 & 0.02 & 0.91 & 1.20 \\
\hline 32 & 28816 & 0.04 & 0.01 & 0.94 & 1.18 \\
\hline 33 & 21943 & 0.03 & 0.01 & 0.94 & 1.17 \\
\hline 34 & 58062 & 0.08 & 0.03 & 0.86 & 1.09 \\
\hline 35 & 84977 & 0.04 & 0.03 & 0.91 & 1.18 \\
\hline 36 & 46100 & 0.09 & 0.03 & 0.85 & 1.12 \\
\hline 37 & 51830 & 0.07 & 0.02 & 0.90 & 1.17 \\
\hline 39 & 64939 & 0.06 & 0.02 & 0.89 & 1.14 \\
\hline 40 & 32175 & 0.07 & 0.03 & 0.88 & 1.16 \\
\hline 41 & 14559 & 0.11 & 0.03 & 0.85 & 1.14 \\
\hline 42 & 17275 & 0.08 & 0.02 & 0.89 & 1.16 \\
\hline
\end{tabular}

Notes: Coefficients are measured using Ackerberg et al. (2006) production function estimation and assuming a Translog production function. The markup is the materials output coefficient divided by the materials cost share. 
Table 4. Exporting Firms' Responses to ETRs

\begin{tabular}{|c|c|c|c|c|c|c|}
\hline & Quantity & Price & Quantity & Quantity & Price & Price \\
\hline $\begin{array}{l}\text { Rebates/VA } \\
\mathrm{T}(\mathrm{RV})\end{array}$ & $\begin{array}{c}0.299^{* * *} \\
(0.069)\end{array}$ & $\begin{array}{l}-0.013 \\
(0.022)\end{array}$ & $\begin{array}{c}-1.740^{* * *} \\
(0.624)\end{array}$ & & $\begin{array}{l}1.361^{* * *} \\
(0.501)\end{array}$ & \\
\hline HS6 tariffs & $\begin{array}{l}-0.003 \\
(0.013)\end{array}$ & $\begin{array}{l}0.004 \\
(0.006)\end{array}$ & $\begin{array}{c}-0.051 \\
(0.053)\end{array}$ & $\begin{array}{l}-0.043 \\
(0.050)\end{array}$ & $\begin{array}{l}-0.023 \\
(0.040)\end{array}$ & $\begin{array}{l}-0.016 \\
(0.036)\end{array}$ \\
\hline Eligible & & & $\begin{array}{r}-0.873^{* *} \\
(0.409)\end{array}$ & $\begin{array}{l}0.258^{* *} \\
(0.124)\end{array}$ & $\begin{array}{l}-0.003 \\
(0.149)\end{array}$ & $\begin{array}{c}-0.770^{* * *} \\
(0.046)\end{array}$ \\
\hline $\begin{array}{l}\text { RV*Eligibl } \\
\mathrm{e}\end{array}$ & & & $\begin{array}{c}1.349^{* * *} \\
(0.367)\end{array}$ & & $\begin{array}{c}-0.807^{* * *} \\
(0.169)\end{array}$ & \\
\hline$>=2004$ & & & & $\begin{array}{l}1.183^{* * *} \\
(0.378)\end{array}$ & & $\begin{array}{l}-0.333 \\
(0.640)\end{array}$ \\
\hline $\begin{array}{l}>=2004 * \text { Eli } \\
\text { gible }\end{array}$ & & & & $\begin{array}{l}0.066 \\
(0.043)\end{array}$ & & $\begin{array}{c}0.132^{* * *} \\
(0.024)\end{array}$ \\
\hline $\begin{array}{l}>=2004 * \mathrm{Ta} \\
\text { riff }\end{array}$ & & & & $\begin{array}{l}-0.019 \\
(0.031)\end{array}$ & & $\begin{array}{l}-0.003 \\
(0.022)\end{array}$ \\
\hline FEs & $\begin{array}{c}\text { Firm-Prod, } \\
\text { Year }\end{array}$ & $\begin{array}{c}\text { Firm-Prod, } \\
\text { Year }\end{array}$ & Year-HS2 & Year-HS2 & Year-HS2 & Year-HS2 \\
\hline r2 & 0.003 & 0.015 & 0.142 & 0.142 & 0.248 & 0.247 \\
\hline $\mathrm{N}$ & 972256 & 972256 & 972256 & 982071 & 972256 & 982071 \\
\hline
\end{tabular}

Notes: $(1) *, * *, * * *$ Significant at the $10 \%, 5 \%$, and $1 \%$ level. Robust standard errors are in parentheses. (2) Prices and quantities (aggregated across destinations to the HS8 product level) are in logs. This table includes only exporting firms. Non-eligible firms are exporters that are "processors with supplied materials" and eligible firms are the rest of the exporting firms. We cluster standard errors at the HS4 product level. 
Table 5. 2004 Policy Change on Eligible vs Non-Eligible Firms

\begin{tabular}{|c|c|c|c|c|c|c|c|c|c|}
\hline & Markup & $\begin{array}{l}\text { Markup } \\
\text { (PCM) }\end{array}$ & Profit & $\begin{array}{l}\text { VA Per } \\
\text { Worker }\end{array}$ & Revenue & TFP & Materials & Labor & $\begin{array}{c}\text { Material } \\
\text { Share }\end{array}$ \\
\hline Year $>=2004$ & $\begin{array}{l}0.026^{* *} \\
(0.013)\end{array}$ & $\begin{array}{c}0.057^{* *} \\
(0.024)\end{array}$ & $\begin{array}{l}0.064^{* *} \\
(0.032)\end{array}$ & $\begin{array}{r}0.438^{* * *} \\
(0.163)\end{array}$ & $\begin{array}{c}0.552^{* * *} \\
(0.123)\end{array}$ & $\begin{array}{c}0.107^{* *} \\
(0.044)\end{array}$ & $\begin{array}{c}0.509^{* * *} \\
(0.119)\end{array}$ & $\begin{array}{l}0.092 \\
(0.078)\end{array}$ & $\begin{array}{l}-0.006 \\
(0.010)\end{array}$ \\
\hline Rebate Eligible & $\begin{array}{c}0.021^{* * *} \\
(0.004)\end{array}$ & $\begin{array}{l}0.008 \\
(0.009)\end{array}$ & $\begin{array}{l}0.015 \\
(0.010)\end{array}$ & $\begin{array}{c}-0.194^{* * *} \\
(0.038)\end{array}$ & $\begin{array}{r}0.159^{* * * *} \\
(0.031)\end{array}$ & $\begin{array}{r}-0.088^{* * *} \\
(0.031)\end{array}$ & $\begin{array}{r}0.151^{* * *} \\
(0.030)\end{array}$ & $\begin{array}{r}0.153^{* * *} \\
(0.027)\end{array}$ & $\begin{array}{r}-0.011^{* * *} \\
(0.003)\end{array}$ \\
\hline$>=2004 *$ Elig. & $\begin{array}{c}-0.004^{* * *} \\
(0.001)\end{array}$ & $\begin{array}{c}-0.003^{*} \\
(0.002)\end{array}$ & $\begin{array}{r}-0.005^{* * *} \\
(0.002)\end{array}$ & $\begin{array}{l}0.004 \\
(0.008)\end{array}$ & $\begin{array}{c}-0.044^{* * *} \\
(0.006)\end{array}$ & $\begin{array}{l}-0.003 \\
(0.004)\end{array}$ & $\begin{array}{c}-0.035^{* * *} \\
(0.006)\end{array}$ & $\begin{array}{c}-0.037^{* * *} \\
(0.005)\end{array}$ & $\begin{array}{c}0.002^{* * *} \\
(0.000)\end{array}$ \\
\hline $\mathrm{K} / \mathrm{L}$ & $\begin{array}{c}0.001^{* * *} \\
(0.000)\end{array}$ & $\begin{array}{c}0.004^{* * *} \\
(0.001)\end{array}$ & $\begin{array}{r}0.009^{* * *} \\
(0.001)\end{array}$ & $\begin{array}{r}0.189^{* * *} \\
(0.005)\end{array}$ & $\begin{array}{c}0.062^{* * *} \\
(0.002)\end{array}$ & $\begin{array}{c}0.033^{* * *} \\
(0.003)\end{array}$ & $\begin{array}{c}0.061^{* * *} \\
(0.002) \\
\end{array}$ & & $\begin{array}{c}0.003^{* * *} \\
(0.000)\end{array}$ \\
\hline HHI & $\begin{array}{l}0.004 \\
(0.005)\end{array}$ & $\begin{array}{l}-0.002 \\
(0.021)\end{array}$ & $\begin{array}{l}0.021 \\
(0.017)\end{array}$ & $\begin{array}{l}0.203^{* *} \\
(0.088)\end{array}$ & $\begin{array}{l}0.015 \\
(0.059)\end{array}$ & $\begin{array}{l}0.038 \\
(0.061)\end{array}$ & $\begin{array}{l}-0.011 \\
(0.059)\end{array}$ & $\begin{array}{l}-0.053 \\
(0.048)\end{array}$ & $\begin{array}{l}0.003 \\
(0.004)\end{array}$ \\
\hline Tariff*Post04 & $\begin{array}{l}-0.003 \\
(0.002)\end{array}$ & $\begin{array}{r}0.004^{* * *} \\
(0.001)\end{array}$ & $\begin{array}{l}0.003^{* *} \\
(0.001)\end{array}$ & $\begin{array}{l}-0.001 \\
(0.007)\end{array}$ & $\begin{array}{c}0.025^{* *} \\
(0.012)\end{array}$ & $\begin{array}{l}-0.003 \\
(0.003)\end{array}$ & $\begin{array}{l}0.022^{* *} \\
(0.011)\end{array}$ & $\begin{array}{l}0.008 \\
(0.006)\end{array}$ & $\begin{array}{l}0.001^{*} \\
(0.001)\end{array}$ \\
\hline Tariff*Eligible & $\begin{array}{l}0.001 \\
(0.001)\end{array}$ & $\begin{array}{l}-0.001 \\
(0.002)\end{array}$ & $\begin{array}{l}-0.004 \\
(0.003)\end{array}$ & $\begin{array}{c}-0.017^{*} \\
(0.010)\end{array}$ & $\begin{array}{l}0.002 \\
(0.007)\end{array}$ & $\begin{array}{l}-0.005 \\
(0.007)\end{array}$ & $\begin{array}{l}0.005 \\
(0.007) \\
\end{array}$ & $\begin{array}{l}0.006 \\
(0.004)\end{array}$ & $\begin{array}{l}-0.000 \\
(0.001)\end{array}$ \\
\hline Inp-Tar*Post04 & $\begin{array}{l}0.006 \\
(0.006)\end{array}$ & $\begin{array}{c}-0.020^{* * *} \\
(0.008)\end{array}$ & $\begin{array}{l}-0.015 \\
(0.011)\end{array}$ & $\begin{array}{c}-0.118^{* *} \\
(0.051)\end{array}$ & $\begin{array}{c}-0.138^{* * *} \\
(0.043)\end{array}$ & $\begin{array}{c}-0.036^{* *} \\
(0.015)\end{array}$ & $\begin{array}{c}-0.129^{* * *} \\
(0.042)\end{array}$ & $\begin{array}{l}0.016 \\
(0.025)\end{array}$ & $\begin{array}{r}-0.006^{* *} \\
(0.003)\end{array}$ \\
\hline Inp-Tar*Eligible & $\begin{array}{r}-0.007^{* * *} \\
(0.002)\end{array}$ & $\begin{array}{l}-0.006 \\
(0.004)\end{array}$ & $\begin{array}{l}-0.002 \\
(0.004)\end{array}$ & $\begin{array}{c}0.061^{* * *} \\
(0.018)\end{array}$ & $\begin{array}{r}-0.044^{* * *} \\
(0.013)\end{array}$ & $\begin{array}{l}0.034^{* *} \\
(0.014)\end{array}$ & $\begin{array}{r}-0.043^{* * *} \\
(0.013)\end{array}$ & $\begin{array}{c}-0.041^{* * *} \\
(0.010)\end{array}$ & $\begin{array}{c}0.004^{* * *} \\
(0.001)\end{array}$ \\
\hline Foreign share & $\begin{array}{l}0.000 \\
(0.000)\end{array}$ & $\begin{array}{c}-0.010^{* * *} \\
(0.002)\end{array}$ & $\begin{array}{l}0.003^{* *} \\
(0.001)\end{array}$ & $\begin{array}{r}-0.057^{* * *} \\
(0.006)\end{array}$ & $\begin{array}{c}-0.049^{* * *} \\
(0.005)\end{array}$ & $\begin{array}{l}0.003 \\
(0.005)\end{array}$ & $\begin{array}{r}-0.068^{* * *} \\
(0.005)\end{array}$ & $\begin{array}{r}0.027^{* * *} \\
(0.004)\end{array}$ & $\begin{array}{c}-0.005^{* * *} \\
(0.000)\end{array}$ \\
\hline $\mathrm{r} 2$ & 0.838 & 0.328 & 0.032 & 0.583 & 0.841 & 0.539 & 0.837 & 0.861 & 0.705 \\
\hline $\mathrm{N}$ & 418304 & 418304 & 418304 & 417611 & 418304 & 418304 & 417611 & 417611 & 417611 \\
\hline
\end{tabular}

Notes: $(1) *, * *, * * *$ Significant at the $10 \%, 5 \%$, and $1 \%$ level. Robust standard errors are in parentheses.

(2) All regressions include year-industry interacted fixed effects. All outcome variables are in logs except profit and material sha (ratios). All regressions include a lag of the dependent variable. Other than the eligibility and post 2004 variables, we include labor-capital ratio, Herfindahl concentration ratio for 4 digit industry, output and input tariffs, the interaction of the tariffs with the post 2004 dummy, firm age, a province ID, capital-output ratio, and the firm's foreign ownership share. Only some of those regressors are shown in the table above. Standard errors are clustered at the 4 digit CIC industry level. 
Table 6. Second Moments of Markup and TFP Distributions: Effect of Rebate Rate

\begin{tabular}{|l|c|c|c|c|}
\hline & SD Markup & SD TFPR & COV Mark & COV TFPR \\
\hline \multirow{2}{*}{ Rebates 4-digit } & $-0.0567^{* * *}$ & -0.0530 & $-0.0003^{* *}$ & $0.0028^{* * *}$ \\
& $(0.0167)$ & $(0.0332)$ & $(0.0001)$ & $(0.0010)$ \\
\hline \multirow{2}{*}{ Tariffs } & -0.0026 & $-0.0152^{* *}$ & -0.0000 & -0.0002 \\
& $(0.0060)$ & $(0.0076)$ & $(0.0000)$ & $(0.0004)$ \\
\hline \multirow{2}{*}{ Input Tariffs } & 0.0261 & 0.0109 & 0.0001 & -0.0002 \\
& $(0.0178)$ & $(0.0264)$ & $(0.0001)$ & $(0.0010)$ \\
\hline \multirow{2}{*}{ Import Intensity } & 0.0109 & $0.0580^{* *}$ & 0.0002 & -0.0008 \\
& $(0.0139)$ & $(0.0285)$ & $(0.0002)$ & $(0.0018)$ \\
\hline \multirow{2}{*}{ Export Intensity } & -0.0008 & 0.0036 & -0.0000 & -0.0005 \\
& $(0.0085)$ & $(0.0112)$ & $(0.0001)$ & $(0.0007)$ \\
\hline \multirow{2}{*}{ HHI } & -0.0127 & $-0.1368^{*}$ & $0.0008^{*}$ & -0.0066 \\
& $(0.0325)$ & $(0.0728)$ & $(0.0005)$ & $(0.0052)$ \\
\hline \multirow{2}{*}{ For. own (avg) } & -0.0416 & 0.0454 & -0.0006 & $0.0117^{*}$ \\
\hline r2 & $(0.0310)$ & $(0.0944)$ & $(0.0005)$ & $(0.0062)$ \\
\hline $\mathrm{N}$ & 0.730 & 0.945 & 0.277 & 0.345 \\
\hline
\end{tabular}

Notes: $(1) *, * *, * * *$ Significant at the $10 \%, 5 \%$, and $1 \%$ level. Robust standard errors are in parentheses.

(2) All regressions include separate year and industry fixed effects. Standard deviations and means are taken of the logged variable. All independent variables are at 4 digit CIC industry average. Rebates are the average of eligible firms. 
Table 7: Second Moments of Markup and TFP Distributions: Diff-in-Diff

\begin{tabular}{|c|c|c|c|c|}
\hline & SD Markup & SD TFPR & COV Mark & COV TFPR \\
\hline Avg Markup & $\begin{array}{l}0.717^{* * *} \\
(0.1542)\end{array}$ & & $\begin{array}{l}0.004^{* *} \\
(0.0019)\end{array}$ & \\
\hline$>=2004$ & $\begin{array}{l}-0.014 \\
(0.0139)\end{array}$ & $\begin{array}{l}-0.019 \\
(0.0203)\end{array}$ & $\begin{array}{l}-0.000 \\
(0.0001)\end{array}$ & $\begin{array}{c}0.001 \\
(0.0012)\end{array}$ \\
\hline Share Eligible & $\begin{array}{l}-0.139 \\
(0.0954)\end{array}$ & $\begin{array}{c}0.266 \\
(0.1950)\end{array}$ & $\begin{array}{l}-0.002^{* *} \\
(0.0010)\end{array}$ & $\begin{array}{l}0.030^{*} \\
(0.0155)\end{array}$ \\
\hline$>=2004 *$ Share & $\begin{array}{l}0.043^{* *} \\
(0.0174)\end{array}$ & $\begin{array}{l}0.056^{*} \\
(0.0326)\end{array}$ & $\begin{array}{c}0.000 \\
(0.0002)\end{array}$ & $\begin{array}{l}-0.004^{*} \\
(0.0026)\end{array}$ \\
\hline SD TFPR & $\begin{array}{l}0.093^{* * *} \\
(0.0239)\end{array}$ & & & \\
\hline Import Intensity & $\begin{array}{c}0.004 \\
(0.0140)\end{array}$ & $\begin{array}{l}0.076^{* * *} \\
(0.0279)\end{array}$ & $\begin{array}{c}0.000 \\
(0.0002)\end{array}$ & $\begin{array}{l}-0.000 \\
(0.0017)\end{array}$ \\
\hline HHI & $\begin{array}{l}-0.037 \\
(0.0368)\end{array}$ & $\begin{array}{l}-0.061 \\
(0.0676)\end{array}$ & $\begin{array}{c}0.001 \\
(0.0005)\end{array}$ & $\begin{array}{l}-0.007 \\
(0.0048)\end{array}$ \\
\hline Avg TFPR & & $\begin{array}{l}-0.159^{* * *} \\
(0.0488)\end{array}$ & & $\begin{array}{l}-0.001 \\
(0.0036)\end{array}$ \\
\hline $\mathrm{r} 2$ & 0.7569 & 0.9538 & 0.3132 & 0.3559 \\
\hline $\mathrm{N}$ & 2097 & 2097 & 2097 & 2097 \\
\hline
\end{tabular}

Notes: $(1) *, * *, * * *$ Significant at the $10 \%, 5 \%$, and $1 \%$ level. Robust standard errors are in parentheses.

(2) All regressions include separate year and industry fixed effects. All second moments are taken of the logged variable. All independent variables are at 4 digit CIC industry average. 


\section{$\underline{\text { Appendix }}$}

\section{Appendix A: Robustness Results}

Table 1A. Effect of Rebate Policy Change on Eligible vs Non-Eligible Firms

\begin{tabular}{|c|c|c|c|c|c|c|c|c|c|c|}
\hline & Markup & $\begin{array}{l}\text { Markup } \\
\text { (PCM) }\end{array}$ & Markup & Profit & $\begin{array}{l}\text { VA Per } \\
\text { Worker }\end{array}$ & Revenue & TFP & Materials & Labor & $\begin{array}{c}\text { Material } \\
\text { Share }\end{array}$ \\
\hline $\begin{array}{l}\text { Rebate/ } \\
\text { VAT: 4- } \\
\text { digit }\end{array}$ & $\begin{array}{l}0.019 \\
(0.023)\end{array}$ & $\begin{array}{c}-0.152^{* * *} \\
(0.032)\end{array}$ & & $\begin{array}{l}-0.031 \\
(0.044)\end{array}$ & $\begin{array}{l}-0.155 \\
(0.169)\end{array}$ & $\begin{array}{c}-0.367^{* *} \\
(0.179)\end{array}$ & $\begin{array}{l}-0.049 \\
(0.062)\end{array}$ & $\begin{array}{c}-0.352^{*} \\
(0.188)\end{array}$ & $\begin{array}{l}0.019 \\
(0.146)\end{array}$ & $\begin{array}{l}-0.003 \\
(0.012)\end{array}$ \\
\hline $\begin{array}{l}\text { Rebate } \\
\text { Eligible }\end{array}$ & $\begin{array}{l}-0.009^{* *} \\
(0.003)\end{array}$ & $\begin{array}{l}-0.010 \\
(0.008)\end{array}$ & $\begin{array}{c}-0.019^{* * *} \\
(0.003)\end{array}$ & $\begin{array}{l}-0.010 \\
(0.011)\end{array}$ & $\begin{array}{c}-0.215^{* * *} \\
(0.048)\end{array}$ & $\begin{array}{l}-0.056 \\
(0.036)\end{array}$ & $\begin{array}{c}-0.091^{* * *} \\
(0.020)\end{array}$ & $\begin{array}{l}-0.025 \\
(0.032)\end{array}$ & $\begin{array}{l}-0.000 \\
(0.029)\end{array}$ & $\begin{array}{l}0.002 \\
(0.003)\end{array}$ \\
\hline $\begin{array}{l}\text { Reb*Eli } \\
\text { g. }\end{array}$ & $\begin{array}{c}0.031^{* * *} \\
(0.004)\end{array}$ & $\begin{array}{l}0.014 \\
(0.012)\end{array}$ & & $\begin{array}{c}0.021^{* *} \\
(0.009)\end{array}$ & $\begin{array}{l}0.106^{* * *} \\
(0.037)\end{array}$ & $\begin{array}{c}0.175^{* * *} \\
(0.033)\end{array}$ & $\begin{array}{l}-0.004 \\
(0.024)\end{array}$ & $\begin{array}{l}0.147^{* * *} \\
(0.032)\end{array}$ & $\begin{array}{l}0.106^{* * *} \\
(0.026)\end{array}$ & $\begin{array}{c}-0.012^{* * *} \\
(0.003)\end{array}$ \\
\hline $\mathrm{K} / \mathrm{L}$ & $\begin{array}{l}0.001^{* * *} \\
(0.000)\end{array}$ & $\begin{array}{l}0.004^{* * *} \\
(0.001)\end{array}$ & $\begin{array}{c}0.001^{* * *} \\
(0.000)\end{array}$ & $\begin{array}{c}0.009^{* * *} \\
(0.001)\end{array}$ & $\begin{array}{l}0.192^{* * *} \\
(0.005)\end{array}$ & $\begin{array}{c}0.062^{* * *} \\
(0.002)\end{array}$ & $\begin{array}{c}0.033^{* * *} \\
(0.003)\end{array}$ & $\begin{array}{c}0.062^{* * *} \\
(0.002)\end{array}$ & & $\begin{array}{l}0.003^{* * *} \\
(0.000)\end{array}$ \\
\hline HHI & $\begin{array}{c}0.009^{* *} \\
(0.004)\end{array}$ & $\begin{array}{l}0.006 \\
(0.022)\end{array}$ & $\begin{array}{l}0.007 \\
(0.004)\end{array}$ & $\begin{array}{l}0.019 \\
(0.017)\end{array}$ & $\begin{array}{c}0.227^{* *} \\
(0.091)\end{array}$ & $\begin{array}{l}0.019 \\
(0.059)\end{array}$ & $\begin{array}{l}0.045 \\
(0.061)\end{array}$ & $\begin{array}{l}-0.008 \\
(0.060)\end{array}$ & $\begin{array}{l}-0.056 \\
(0.047)\end{array}$ & $\begin{array}{l}0.001 \\
(0.004)\end{array}$ \\
\hline $\begin{array}{l}\text { Tariff* } \\
\text { Rebate }\end{array}$ & $\begin{array}{l}-0.004 \\
(0.003)\end{array}$ & $\begin{array}{c}-0.030^{* * *} \\
(0.011)\end{array}$ & & $\begin{array}{l}-0.010 \\
(0.012)\end{array}$ & $\begin{array}{l}-0.058 \\
(0.064)\end{array}$ & $\begin{array}{c}-0.119^{* *} \\
(0.049)\end{array}$ & $\begin{array}{l}-0.019 \\
(0.031)\end{array}$ & $\begin{array}{c}-0.100^{* *} \\
(0.049)\end{array}$ & $\begin{array}{l}-0.002 \\
(0.029)\end{array}$ & $\begin{array}{l}0.004 \\
(0.003)\end{array}$ \\
\hline $\begin{array}{l}\text { Tariff*E } \\
\text { ligible }\end{array}$ & $\begin{array}{l}0.001 \\
(0.001)\end{array}$ & $\begin{array}{l}0.000 \\
(0.002)\end{array}$ & & $\begin{array}{l}-0.003 \\
(0.003)\end{array}$ & $\begin{array}{l}-0.012 \\
(0.011) \\
\end{array}$ & $\begin{array}{l}0.006 \\
(0.007)\end{array}$ & $\begin{array}{l}-0.005 \\
(0.007)\end{array}$ & $\begin{array}{l}0.008 \\
(0.007)\end{array}$ & $\begin{array}{l}0.007 \\
(0.004)\end{array}$ & $\begin{array}{l}-0.000 \\
(0.001)\end{array}$ \\
\hline $\begin{array}{l}\text { Inp- } \\
\text { Tar*Re } \\
\text { bate }\end{array}$ & $\begin{array}{l}-0.010 \\
(0.013)\end{array}$ & $\begin{array}{l}0.083^{* * *} \\
(0.020)\end{array}$ & & $\begin{array}{l}0.021 \\
(0.026)\end{array}$ & $\begin{array}{l}0.075 \\
(0.118)\end{array}$ & $\begin{array}{c}0.308^{* * *} \\
(0.101)\end{array}$ & $\begin{array}{l}0.038 \\
(0.054)\end{array}$ & $\begin{array}{c}0.282^{* * *} \\
(0.102)\end{array}$ & $\begin{array}{l}0.030 \\
(0.071)\end{array}$ & $\begin{array}{l}-0.001 \\
(0.007)\end{array}$ \\
\hline $\begin{array}{l}\text { Inp- } \\
\text { Tar*Eli } \\
\text { gible }\end{array}$ & $\begin{array}{c}-0.006^{* * *} \\
(0.001)\end{array}$ & $\begin{array}{l}-0.005 \\
(0.004)\end{array}$ & & $\begin{array}{l}-0.001 \\
(0.004)\end{array}$ & $\begin{array}{l}0.035^{*} \\
(0.019)\end{array}$ & $\begin{array}{l}-0.026^{* *} \\
(0.012)\end{array}$ & $\begin{array}{l}0.036^{* * *} \\
(0.014)\end{array}$ & $\begin{array}{l}-0.028^{* *} \\
(0.012)\end{array}$ & $\begin{array}{c}-0.021^{* *} \\
(0.009)\end{array}$ & $\begin{array}{c}0.003^{* * *} \\
(0.001)\end{array}$ \\
\hline $\begin{array}{l}\text { Foreign } \\
\text { share }\end{array}$ & $\begin{array}{l}0.000 \\
(0.000)\end{array}$ & $\begin{array}{c}-0.007^{* * *} \\
(0.002)\end{array}$ & $\begin{array}{l}0.000 \\
(0.000)\end{array}$ & $\begin{array}{l}0.002 \\
(0.001)\end{array}$ & $\begin{array}{c}\overline{-}^{* * * *} \\
0.054^{* *} \\
(0.006)\end{array}$ & $\begin{array}{c}-0.051^{* * *} \\
(0.005)\end{array}$ & $\begin{array}{l}0.004 \\
(0.005)\end{array}$ & $\begin{array}{c}-0.067^{* * *} \\
(0.005)\end{array}$ & $\begin{array}{l}0.026^{* * *} \\
(0.004)\end{array}$ & $\begin{array}{c}-0.005^{* * *} \\
(0.000)\end{array}$ \\
\hline $\begin{array}{l}\text { Lag } \\
\text { Reb*Eli } \\
\text { g }\end{array}$ & & & $\begin{array}{l}0.028^{* * *} \\
(0.005)\end{array}$ & & & & & & & \\
\hline $\mathrm{r} 2$ & 0.838 & 0.287 & 0.839 & 0.032 & 0.581 & 0.841 & 0.539 & 0.837 & 0.861 & 0.702 \\
\hline $\mathrm{N}$ & 417578 & 402148 & 416447 & 417578 & 416886 & 417578 & 417578 & 416886 & 416886 & 416886 \\
\hline
\end{tabular}

Notes: (1) *,**,*** Significant at the $10 \%, 5 \%$, and $1 \%$ level. Robust standard errors are in parentheses.

(2) All regressions include interacted industry-year fixed effects. All outcome variables are in logs except profit and material share (ratios regressions include a lag of the dependent variable. Other than the eligibility and rebate variables, we include labor-capital ratio, Herfi concentration ratio for 4 digit industry, output and input tariffs, the interaction of the tariffs with the post 2004 dummy, firm age, a provi capital-output ratio, and the firm's foreign ownership share. Only some of those are included in the table above. Standard errors are clust digit CIC industry level 
Table 2A: Second Order Moments of the Markup and TFPR Distributions: Diff-in-Diff Using Rebate Level.

\begin{tabular}{|l|c|c|c|c|}
\hline & SD Markup & SD TFPR & COV Mark & COV TFPR \\
\hline \multirow{2}{*}{ Avg Markup } & $\begin{array}{l}0.850^{* * *} \\
(0.1127)\end{array}$ & & $\begin{array}{c}0.001 \\
(0.0009)\end{array}$ & \\
\hline \multirow{2}{*}{ Rebates 4-digit } & -0.018 & 0.007 & -0.000 & 0.000 \\
& $(0.0151)$ & $(0.0239)$ & $(0.0001)$ & $(0.0013)$ \\
\hline \multirow{2}{*}{ Share Eligible } & -0.013 & 0.108 & 0.001 & $-0.013^{* *}$ \\
& $(0.0480)$ & $(0.0872)$ & $(0.0007)$ & $(0.0062)$ \\
\hline \multirow{2}{*}{ Rebates*Share } & -0.001 & -0.166 & $-0.002^{*}$ & $0.023^{* *}$ \\
& $(0.0567)$ & $(0.1110)$ & $(0.0009)$ & $(0.0096)$ \\
\hline \multirow{2}{*}{ SD TFPR } & $0.039^{* *}$ & & & \\
& $(0.0162)$ & & & -0.001 \\
Import Intensity & -0.001 & $0.080^{* *}$ & 0.000 & $(0.0017)$ \\
\hline \multirow{2}{*}{ HHI } & $(0.0123)$ & $(0.0363)$ & $(0.0002)$ & -0.007 \\
& $-0.031^{*}$ & $0.278^{* * *}$ & $0.001^{*}$ & $(0.0049)$ \\
\hline \multirow{2}{*}{ Avg TFPR } & $(0.0173)$ & $(0.0474)$ & $(0.0005)$ & -0.001 \\
\hline r2 & & $-0.347^{* * *}$ & & $(0.0032)$ \\
\hline N & 0.6506 & $(0.0381)$ & & 0.3575 \\
\hline
\end{tabular}

Notes: $(1) *, * *, * * *$ Significant at the $10 \%, 5 \%$, and $1 \%$ level. Robust standard errors are in parentheses.

(2) All regressions include separate year and industry fixed effects. All second moments are taken of the logged variable. All independent variables are at 4 digit CIC industry average. Rebates are an average of rebates for eligible firm within the industry.

\section{Appendix B: Bilateral Export Tax Rebates}

As a combination of value added taxes and rebates for exporters are used by many nations in the world -- and allowed by the WTO -- a bilateral symmetry in ETR policy may be of interest as well. We show that both cut-off costs of entering the domestic market and export market of country $H$ falls in the case of bilateral ETR policy.

Case 2: Both countries implement the same trade policy with equivalent ETR rates, $t_{H}=t_{F}=t$. Cut-offs in these countries are 


$$
c_{D}^{l}=\left\{\frac{\gamma \phi}{L^{l}} \frac{1}{1+\rho\left[(t+1)+\frac{k t(k t+3 t+2)}{2(t+1)}\right]}\right\}^{1 / k+2}, \quad(l=H, F)
$$

The number of firms selling in country $H$ includes domestic producers and exporters, thus the average price $\bar{p}^{H}$ in country $H$ can be written

$$
\bar{p}^{H}=\frac{1}{N_{E}^{H} G^{H}\left(c_{D}^{H}\right)+N_{E}^{F} G^{F}\left(\frac{c_{D}^{H}}{\tau^{H}}\right)}\left[\int_{0}^{c_{D}^{H}} \frac{1}{2}\left(c_{D}^{H}+c\right) d c+\int_{0}^{c_{D}^{H} / \tau^{H}} \frac{1}{2}\left(c_{D}^{H}+\frac{\tau^{H}}{1+t_{F}} c\right) d c\right]
$$

Here, $N_{E}^{l}(l=H, F)$ are the total entrants in both countries, there are $N_{E}^{H} G^{H}\left(c_{D}^{H}\right)$ domestic producers and $N_{E}^{F} G^{F}\left(\frac{c_{D}^{H}}{\tau^{H}}\right)$ exporters selling in country $H$. So $\bar{p}^{H}$ can be simplified as

$$
\bar{p}^{H}=\frac{1}{2} \frac{N_{E}^{H} \frac{2 k+1}{k+1}\left(c_{M}\right)^{-k}+N_{E}^{F}\left(1+\frac{k}{k+1} \cdot \frac{1}{1+t_{F}}\right)\left(c_{M}^{*}\right)^{-k}\left(\tau^{H}\right)^{-k}}{N_{E}^{H}\left(c_{M}\right)^{-k}+N_{E}^{F}\left(c_{M}{ }^{*}\right)^{-k}\left(\tau^{H}\right)^{-k}} c_{D}^{H}
$$

Where $1 / c_{M}, 1 / c_{M}{ }^{*}$ respectively represent for country $H$ and country $F$ 's lower productivity bound. Due to symmetry, it is assumed that an ETR policy with a same ETR rate is implemented. Equation (20) can be further simplified as follows

$$
\bar{p}^{H}=\frac{1}{2} \frac{\frac{2 k+1}{k+1}+\left(1+\frac{k}{k+1} \cdot \frac{1}{1+t}\right) \rho}{1+\rho} c_{D}^{H}
$$

Based on equation (5), we obtain

$$
c_{D}^{H}=\frac{\gamma \alpha+\eta N^{H} \bar{p}^{-H}}{\eta \mathrm{N}^{H}+\gamma}
$$

Where $\mathrm{N}^{H}$ is the total number of entrants in country $H$ :

$\left.\mathrm{N}^{H}=N_{E}^{H} G^{H}\left(c_{D}^{H}\right)+N_{E}^{F} G^{F}\left(\frac{c_{D}^{H}}{\tau^{H}}\right)\right)$.

By using equation (22), we obtain 


$$
N^{H}=\frac{\gamma}{\eta \frac{2+\rho-\frac{2 k+1}{k+1}-\frac{k}{k+1} \frac{\rho}{1+t}}{2(1+\rho)}}\left\{\alpha \frac{\gamma \phi}{L}\left[1+\rho\left((t+1)+\frac{k t(k t+3 t+2)}{2(t+1)}\right)\right]^{-\frac{1}{k+2}}-1\right\}
$$

The number of entrants in country $H$ in MO model is to be:

$$
N=\frac{2(k+1) \gamma}{\eta}\left[\alpha \frac{\gamma \phi}{L}(1+\rho)^{-\frac{1}{k+2}}-1\right]
$$

Then,

$$
\frac{N^{H}}{N}=\frac{1+\rho}{2+\rho-\frac{2 k+1}{k+1}-\frac{k}{k+1} \frac{\rho}{1+t}} \frac{\alpha\left\{\frac{\gamma \phi}{L}\left[1+\rho\left((t+1)+\frac{k t(k t+3 t+2)}{2(t+1)}\right)\right]\right\}^{-\frac{1}{k+2}}-1}{\alpha\left[\frac{\gamma \phi}{L}(1+\rho)\right]^{-\frac{1}{k+2}}-1}
$$

It's hard to compare $N^{H}$ and $N$ directly, we use the numerical simulation to work. We set values for parameters as follows: $\tau=1.83, k=4.25, c_{M}=1, f_{E}=1$, $\alpha=10, \gamma=2, \eta=10, L=50$. The result is in Figure 1A.

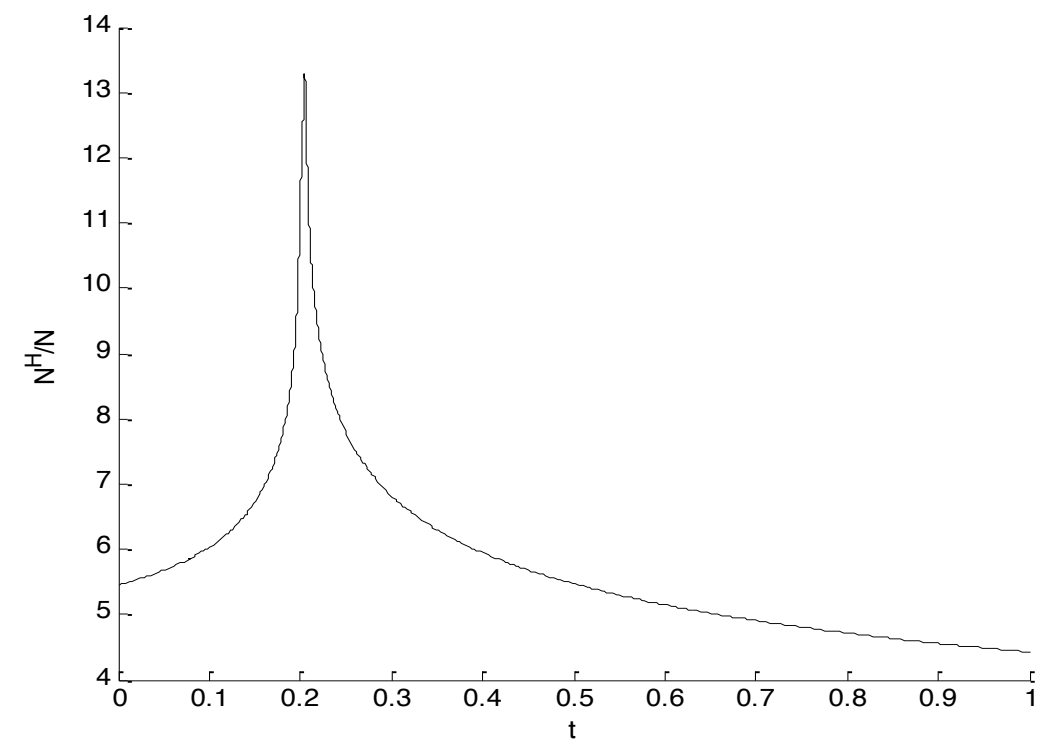

Figure 1A: Numerical simulation: firm numbers in domestic market before and after ETR policy

It finds that $\frac{N^{H}}{N}>1$ will be established as long as the ETR rate is in $[0,1]$. That is to say, numbers of entrants in domestic market with bilateral ETR policy 
are larger than that in the absence of the ETR policy. In such case, competition in domestic market would increase, pro-competitive effects would be more pronounced, and the cut-off cost of entering domestic market would fall.

Similarly, as the two countries are symmetric, we can conclude that numbers of entrants in foreign market are also larger under the ETR policy than that in the absence of the ETR policy. That is the exporters of country $\mathrm{H}$ would face tougher competition in export market, pro-competitive effects would be strengthened and the cut-off cost of entering the export market would fall. As cut-offs in both markets fall, firm markups would decrease according the relationship between the firm markup and both cut-offs. From equation (18), we have $\frac{\partial c_{D}^{l}}{\partial t}<0{ }^{1} ; c_{D}^{l}$ and $t$ are negatively correlated.

Proposition 1A: Under the symmetric case, when other conditions are constant, the ETR policy will decrease the domestic firms' markups. The ETR rate is negatively related to firm markups.

$$
\begin{aligned}
& { }^{1} \text { From equation (15),we get: } \\
& \frac{\partial c_{D}^{l}}{\partial t}=\frac{\partial c_{D}^{l}}{\partial \varphi} \frac{\partial \varphi}{\partial t}=-\frac{1}{k+2} \frac{\gamma \phi}{L^{l}} \frac{\rho^{l}}{\left(1+\rho^{l} \varphi\right)^{2}}\left(\frac{\gamma \phi}{L^{l}} \frac{1}{1+\rho^{l} \varphi}\right)^{-\frac{k+1}{k+2}}\left\{(1+k)+\frac{1}{2} k(k+1)\left[1-\frac{1}{(1+t)^{2}}\right]\right\} \\
& \text {,then, } \frac{\partial \varphi}{\partial t}=(1+k)+\frac{1}{2} k(k+1)\left[1-\frac{1}{(t+1)^{2}}\right]>0, \\
& \frac{\partial c_{D}^{l}}{\partial \varphi}=-\frac{1}{k+2} \frac{\gamma \phi}{L^{l}} \frac{\rho^{l}}{\left(1+\rho^{l} \varphi\right)^{2}}\left(\frac{\gamma \phi}{L^{l}} \frac{1}{1+\rho^{l} \varphi}\right)^{-\frac{k+1}{k+2}}<0 . \text { So, } \frac{\partial c_{D}^{l}}{\partial t}=\frac{\partial c_{D}^{l}}{\partial \varphi} \frac{\partial \varphi}{\partial t}<0 . \text { Similar } \\
& \text { analysis to equation }(15), \text { we can get } \frac{\partial c_{D}^{l}}{\partial t}=\frac{\partial c_{D}^{l}}{\partial \varphi} \frac{\partial \varphi}{\partial t}<0, \text { where } \frac{\partial \varphi}{\partial t}>0, \\
& \frac{\partial c_{D}^{l}}{\partial \varphi}=\frac{1}{k+2}\left(\frac{\gamma \phi}{L^{l}}\right)^{\frac{1}{k+2}}\left(\frac{1-\rho \varphi}{1-\rho^{2} \varphi}\right)^{-\frac{k+1}{k+2}} \frac{\rho^{2}-\rho}{\left(1-\rho^{2} \varphi\right)^{2}}<0
\end{aligned}
$$

